\title{
Mineralogical Setting of Precious Metals at the Assarel Porphyry Copper-Gold Deposit, Bulgaria, as Supporting Information for the Development of New Drill Core 3D XCT-XRF Scanning Technology
}

\author{
Mihaela-Elena Cioacă ${ }^{1, *}$, Marian Munteanu ${ }^{1}$,, Edward P. Lynch ${ }^{2}$, Nikolaos Arvanitidis ${ }^{2}$, \\ Mikael Bergqvist ${ }^{3}$, Gelu Costin ${ }^{4}$, Desislav Ivanov ${ }^{5}$, Viorica Milu ${ }^{1}$, Ronald Arvidsson ${ }^{2}$, \\ Adina Iorga-Pavel ${ }^{1}$, Karin Högdahl ${ }^{6}$ and Ventsislav Stoilov ${ }^{5}$ \\ 1 Geological Institute of Romania, 012271 Bucharest, Romania; marianmunteanu2000@gmail.com (M.M.); \\ viorica_milu@yahoo.com (V.M.); adinaiorga@yahoo.com (A.I.-P.) \\ 2 Geological Survey of Sweden, Box 670, 75128 Uppsala, Sweden; Edward.Lynch@sgu.se (E.P.L.); \\ Nikolaos.Arvanitidis@sgu.se (N.A.); ronald.arvidsson@sgu.se (R.A.) \\ 3 Orexplore, 16440 Kista, Sweden; mikael.bergqvist@orexplore.com \\ 4 Department of Earth, Environmental and Planetary Sciences, Keith-Wiess Geological Laboratories, \\ Rice University, Houston, TX 77005, USA; g.costin@rice.edu \\ 5 Asarel Medet AD, 4500 Panagyurishte, Bulgaria; divanov@asarel.com (D.I.); vstoilov@asarel.com (V.S.) \\ 6 Department of Earth Sciences, Uppsala University, Villavägen 16, 75236 Uppsala, Sweden; \\ karin.hogdahl@geo.uu.se \\ * Correspondence: mihaela.cioaca@igr.ro; Tel.: +40-0314033491
}

Received: 25 September 2020; Accepted: 21 October 2020; Published: 24 October 2020

\begin{abstract}
A petrographic investigation of ore samples from the Assarel porphyry copper deposit in the Srednogorie metallogenic zone (Bulgaria) constrains the setting and character of precious metals $(\mathrm{Au}, \mathrm{Ag}, \mathrm{PGE})$ and related minerals within the deposit. This work supports renewed interest in understanding the deportment of precious metals and provides mineralogical knowledge during the testing and validation of novel drill core 3D X-ray computed tomography-X-ray fluorescence (XCT-XRF) scanning technology being developed as part of the X-MINE project. Scanning electron microscopy-energy dispersive spectrometry (SEM-EDS) results indicate precious metals occur in their native state $(\mathrm{Au}, \mathrm{Ag})$, as sulfides $(\mathrm{Ag})$, sulfosalts $(\mathrm{Au})$, tellurides $(\mathrm{Ag}, \mathrm{Pd})$, and selenides $(\mathrm{Ag})$, and typically form micron-sized inclusions in pyrite and chalcopyrite or are disseminated in the groundmass of the rock. Preservation of early Fe oxide-chalcopyrite \pm bornite assemblage as relics in the more dominant pyrite-chalcopyrite mineralization assemblage supports mineral disequilibrium relationships and multi-stage mineralization events. Several rare minerals (e.g., merenskyite, acanthite, sorosite, tetra-auricupride, auricupride, greenokite, bismuthinite, nagyagite, native $\mathrm{Ni}$ ) are reported for the first time at Assarel and highlight the mineralogical diversity of the ore. The occurrence of precious metals and related minerals at Assarel attest to a complex hydrothermal system that underwent progressive physicochemical changes during the evolution of the mineralizing system (e.g., redox conditions, fluid chemistry).
\end{abstract}

Keywords: precious metals; platinum-group minerals; Ag-Te-S-Se minerals; hydrothermal metallogeny; Assarel; X-MINE

\section{Introduction}

Porphyry-type deposits are the main source for global $\mathrm{Cu}$ and Mo production, while several strategic and high-tech elements such as Re, W, Bi, In, Te and Se may reach economic concentrations 
and be extracted as co-products. Also, many porphyry copper deposits contain economic grades and volumes of $\mathrm{Au}, \mathrm{Ag}$, and even platinum-group elements (PGE) [1-3] making them more amenable to both exploration and mining. From a resource exploitation perspective, the characterization of precious-metal-bearing ( $\mathrm{Au}, \mathrm{Ag}, \mathrm{PGE})$ minerals in porphyry copper deposits is a challenge because of the generally low concentrations of these metals in the ore, their relatively complex mineralogical setting, their sometimes-uneven spatial distribution, and the potential for lower extraction efficiencies at the beneficiation stage [2-5]. Knowledge-based technological solutions that aid the recognition, characterization, and quantification of precious metals in porphyry copper deposits, particularly if integrated with existing exploration and/or mining workflows, should increase the economic viability of a deposit and mining sustainability.

The mineralogical assessment of porphyry $\mathrm{Cu} \pm \mathrm{Au}$ mineralization commonly relies on "conventional" methods of petrographic investigation including optical microscopy, scanning electron microscopy-energy dispersive spectrometry (SEM-EDS), X-ray diffraction analysis, electron microprobe analysis, and fluid inclusion studies [6-8]. These methods are typically time consuming, sample destructive, and yield results that may not immediately influence exploration/mining decision making. Recent advances in drill core scanning and imaging methods based on hyperspectral infrared spectroscopy [9], laser-induced fluorescence spectroscopy [10], laser-induced breakdown spectroscopy [11], laser Raman spectroscopy [12], and X-ray computed tomography [13] offer the potential for relatively rapid and non-destructive mineralogical characterization of ore and rock samples. Importantly, the ability to directly scan newly extracted drill core for mineralogy/geochemistry characterization should facilitate more effective, evidence-based decisions that support on-going exploration, resource definition and/or mine development activities.

A novel technological solution for drill core characterization is the GeoCore X10 instrument being developed by Orexplore (Kista, Sweden) as part of the Horizon 2020-funded X-MINE project (Figure 1) [14]. This instrument uses simultaneously acquired X-ray computed tomography (XCT) and $\mathrm{X}$-ray fluorescence $(\mathrm{XRF})$ data to digitally reconstruct a 3D representation of scanned drill core [15]. From this dataset, rock and ore textural, structural, density, mineralogical, and geochemical information can be visualized and interpreted [15], thus providing new insights into ore mineralogy and its 3D distributions, and input for 3D mineral deposit modelling [16,17]. In principal, the portability of the GeoCore X10 means it can be deployed close to drilling sites, where marked and depth-labelled drill core can be rapidly scanned (at ca. 15 min per $\mathrm{m}$ ) to produce down-hole textural, structural, density, mineralogical and geochemical data in near real-time (Figure 1). A key step in developing the GeoCore X10 instrument is an assessment of its capabilities at active exploration or mine sites, and the evaluation of results obtained from different mineral deposits [16-19]. Thus, the scanning of drill core with different mineralization types and commodities (e.g., $\mathrm{Zn}-\mathrm{Pb}$ massive sulfide versus porphyry $\mathrm{Cu}$ ) allows the results to be compared and contrasted based on primary mineralization characteristics and independently validated using more traditional investigation methods [20]. Such validation preferably requires detailed mineralogical knowledge about the deposit and its contained ore so that any practical or analytical limitations associated with the generated 3D XCT-XRF data can be noted or addressed or used as constraints to refine the results.

This study presents a petrographic investigation of precious metals and related minerals at the Assarel porphyry copper deposit (west-central Bulgaria), one of four actively mined test sites being used to validate drill core 3D XCT-XRF scanning technology within the X-MINE project [14]. Optical microscopy and SEM-EDS analysis of Assarel ore samples are used to constrain the mineralogy and setting of precious-metals-associated $(\mathrm{Au}, \mathrm{Ag}, \mathrm{Pd})$ key hydrothermal mineral assemblages and alteration types. The identified minerals, textural relationships and contained elements affirm $\mathrm{Cu}$ and precious metal mineralization formed within a geochemically complex, multistage magmatic-hydrothermal system. The new mineralogical results highlight the diverse character of the porphyry $\mathrm{Cu}$ ore at Assarel, the potential for precious metal extraction as co-products, and represent important supporting 
information for the ongoing qualitative and quantitative validation of novel 3D XCT-XRF drill core scanning technology that aims to maximize mining efficiencies and sustainability.

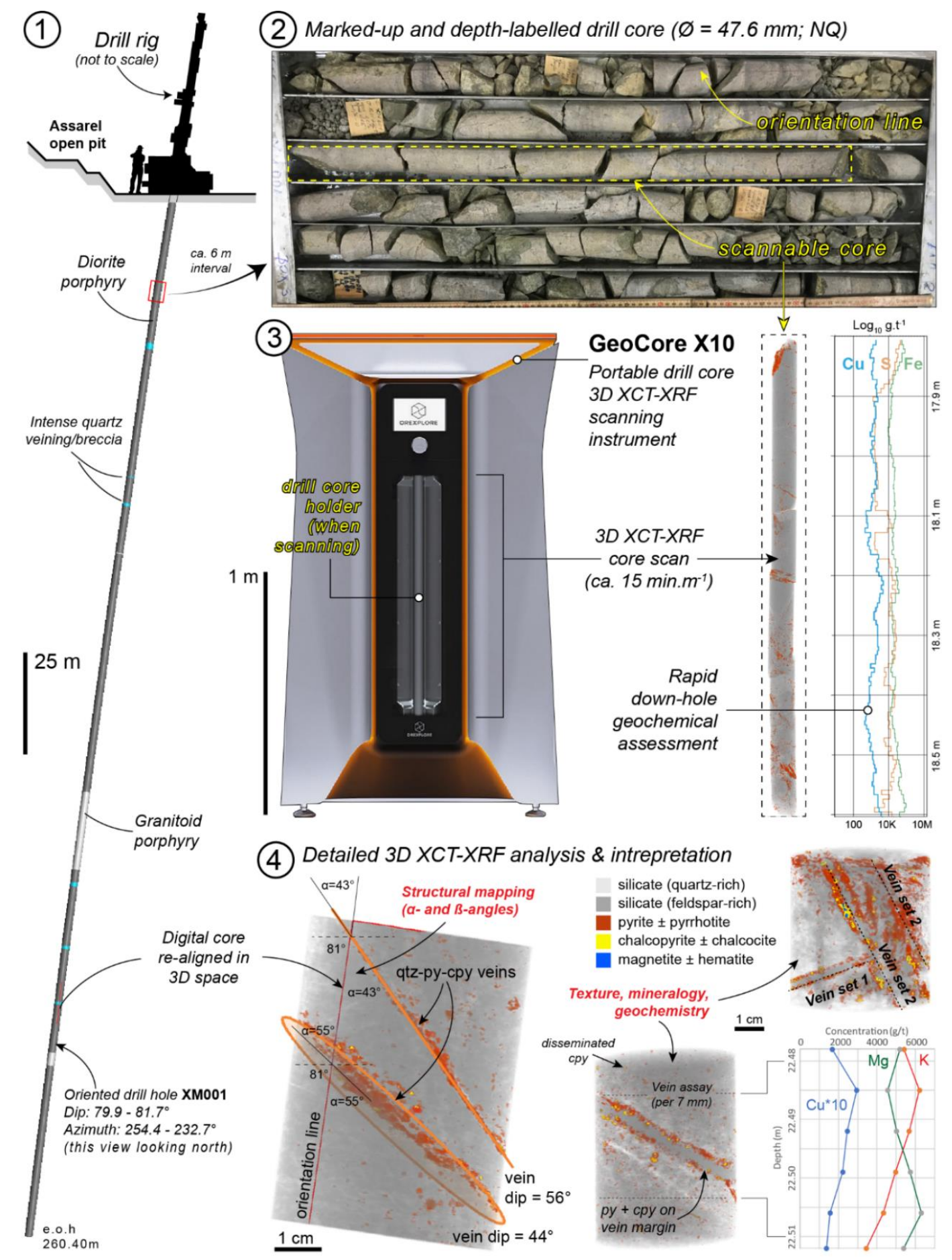

Figure 1. Drill core 3D X-ray computed tomography-X-ray fluorescence (XCT-XRF) scanning technology being developed within the X-MINE project. In this example from Assarel, a proposed workflow for the assessment of a new drill hole (XM001) is illustrated where; drilling and marking of oriented drill core is undertaken (Steps 1 and 2), scanning of suitable core intervals using the GeoCore X10 instrument is performed, producing down-hole 3D tomographic imagery and geochemistry (Step 3), and the measurement of geological structures and interpretation of textures, mineralogy and geochemistry is done (Step 4). Abbreviations: $c p y=$ chalcopyrite, $p y=$ pyrite,$q t z=$ quartz. 


\section{Geological and Metallogenic Setting of the Assarel Ore Deposit}

\subsection{Regional Geological Setting}

A major crustal-scale, L-shaped magmatic-metallogenic belt extends for more than $1500 \mathrm{~km}$ in the south-eastern part of Central Europe (Figure 2A). This belt is often referred to as the Banatitic Magmatic and Metallogenetic Belt (BMMB) [21-23] or Banatite Belt [24], based on the collective name "Banatite" given by von Cotta [25] to Late Cretaceous magmatic rocks (mostly diorite, granodiorite, and granite) in the Banat region of Romania. The alternative name Apuseni-Banat-Timok-Srednogorie (ABTS) magmatic-metallogenic belt is also used [26-29], which encompasses the names of four major lithotectonic areas in the region; namely, the N-S aligned Apuseni and Banat areas of Romania, the NNW-SSE-aligned Timok area in Serbia, and the E-W-trending Srednogorie area in Bulgaria (Figure 2A).

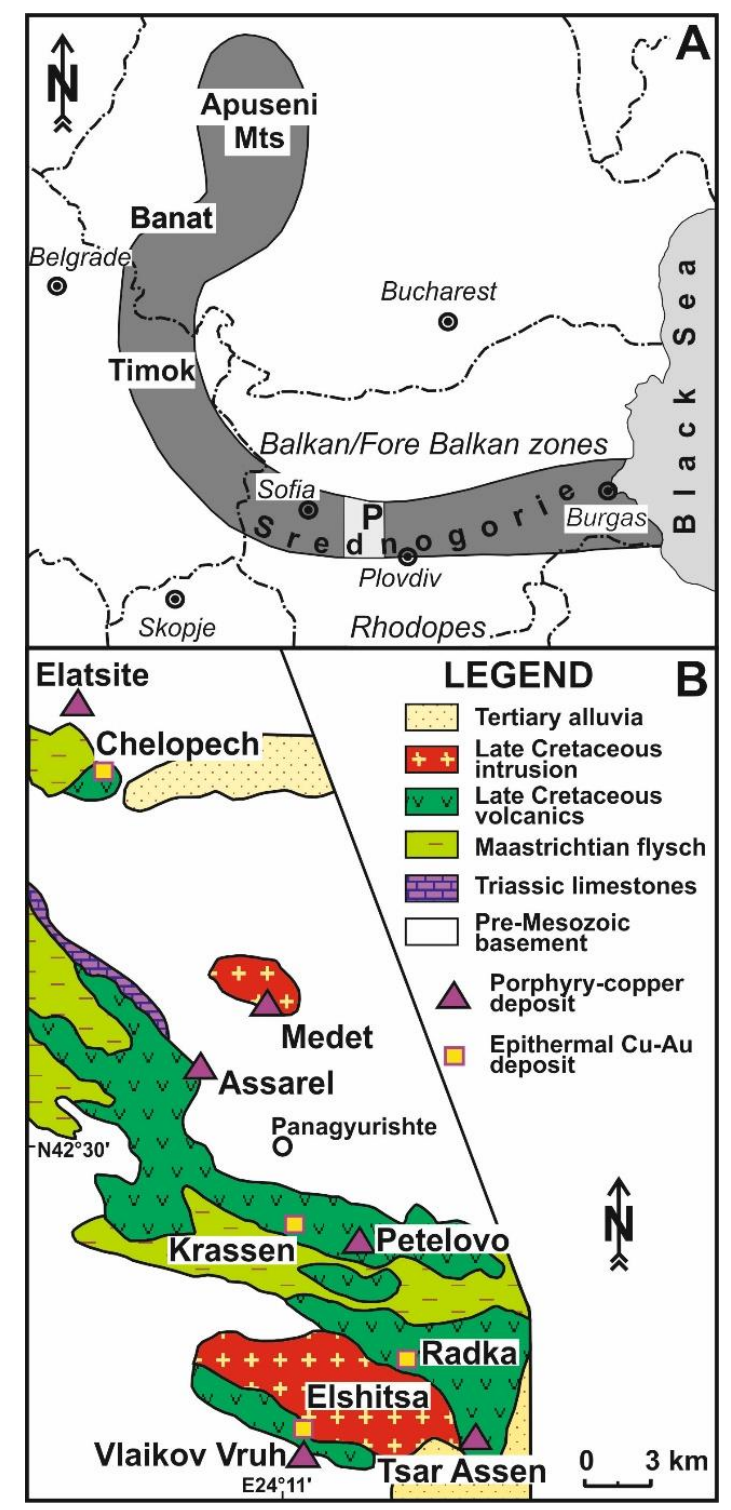

Figure 2. (A) The Apuseni-Banat-Timok-Srednogorie magmatic-metallogenic belt, showing also the location of the Panagyurishte (P) metallogenic district (after Handler et al. [24]). (B) Sketch map of the Panagyurishte district showing the locations of the main epithermal and porphyry mineral systems (after Strashimirov et al. [30]). 
Various geotectonic models (e.g., rift, subduction, post-collisional, back-arc extension) have been proposed for the formation and evolution of the BMMB (e.g., references [21,22,31]). Several paleogeographic reconstructions consider the involvement of northward subduction of the oceanic Vardar crust under several European continental blocks during the Mesozoic [22,32,33]. According to these models, magmatism in the BMMB was generated along a major E-W lineament (suture) and reached the present configuration because of post-subduction displacement and rotation of the Apuseni, Banat, and Timok zones in the Cenezoic. According to Drew [33], oblique subduction gave rise to transpression along a major strike-slip deformation system producing pull-apart extensional structures that provided a locus for Late Cretaceous magmatic and hydrothermal activity. From a metallogenic perspective, the BMMB hosts numerous mineral deposits of varying types including porphyry $\mathrm{Cu} \pm \mathrm{Au} \pm \mathrm{Mo}$, high-sulfidation epithermal $\mathrm{Cu}$-Au and polymetallic skarn mineralization related to Late Cretaceous (92-72 Ma) volcanic and plutonic complexes [21,22,29,31-34].

The Srednogorie segment of the BMMB is commonly divided into the western, central and eastern Srednogorie areas [26,35,36]. The Panagyurishte ore district [22,37] has an NNW-SSE lithostratigraphic-structural trend that transects the central Srednogorie zone of the BMMB $[24,37]$ (Figure 2). Because of its specific lithotectonic framework, the Panagyurishte ore district was also referred to as the Pangyurishte corridor [24,36,38] or the Panagyurishte trough [26].

In the Panagyurishte ore district, a pre-Cretaceous basement consists of Precambrian to Cambrian metamorphic rocks, Paleozoic intrusions (mostly granitoids), and Late Paleozoic-Triassic sedimentary successions [37,39]. Late Cretaceous rocks comprise a Turonian sedimentary complex and a Turonian-Campanian volcanogenic complex with associated intrusive bodies, the latter complex being overlain by Maastrichtian (flysch), Tertiary, and Quaternary sedimentary successions [28,37,39]. Late Cretaceous magmatic rocks are widely distributed basaltic andesitic to dacitic volcanic rocks, and dioritic to granitic and lesser gabbroic subvolcanic and plutonic bodies, all showing broadly calc-alkaline to high-K calc-alkaline compositions [34]. Local lithological transitions within the volcanic sequences to latite, shoshonite, trachydacite, and trachyte are mentioned by several authors $[27,37,39]$. Late Cretaceous magmatic and hydrothermal activity records a temporal migration from north to south [34,37] from ca. $92 \mathrm{Ma}$ at Elatsite to ca. 89-91 Ma at Assarel-Medet to 85-87 Ma at Vlaykov Vruh $[29,34,40-42]$. Geochemical and isotopic signatures of Late Cretaceous magmatic rocks in the region suggest precursor melts generated in a mantle source and were variably modified by the addition of crustal materials, with crustal contamination decreasing from north to south $[24,41]$.

More than 150 ore deposits and occurrences are known in the Panagyurishte district, mostly consisting of porphyry copper and coeval high-sulfidation $\mathrm{Cu}-\mathrm{Au}$ epithermal types [39]. The largest deposits (by tonnage) are the porphyry copper deposits of Elatsite, Assarel, and Medet and the epithermal gold deposit at Chelopech (Figure 2B).

\subsection{Major Ore and Alteration Mineral Assemblages in the Panagyurishte District}

Several hydrothermal mineral assemblages comprising a combination of ore, gangue, and alteration minerals, typically with specific textural features, spatial distributions, and/or paragenetic inter-relationships, have been identified at the porphyry copper deposits from the Panagyurishte ore district $[23,27,28,30,37,43-47]$. The character of the main mineral assemblages recognized are summarized below.

1. Magnetite-hematite ( \pm ilmenite, rutile) \pm bornite, chalcopyrite is an early mineral assemblage. Tarkian et al. [23] refer to this assemblage as "magnetite-chalcopyrite-bornite" at the Elatsite deposit, mentioning the hematite as a secondary phase formed on magnetite.

2. Quartz-pyrite-chalcopyrite is the main $\mathrm{Cu}$-bearing mineral association, related to propylitic, sericitic and transitional sericitic-propylitic alteration of the host rocks; it occurs as veinlets, small nests and disseminations.

3. Quartz-molybdenite occurs in the inner parts of the deposits (spatially associated with the quartz-pyrite-chalcopyrite assemblage), sometimes in veinlets. 
4. Quartz-pyrite containing milky quartz and subhedral to euhedral pyrite aggregates; it locally occurs in veins and veinlets.

5. Quartz-sphalerite-galena (pyrite, chalcopyrite) occurs as veins in the upper and marginal parts of deposits.

6. A supergene alteration assemblage containing variable amounts of chalcocite, covellite, malachite, azurite, and Fe-hydroxide is also known from the porphyry $\mathrm{Cu}$ deposits.

Both porphyry $\mathrm{Cu}$ and epithermal $\mathrm{Cu}-\mathrm{Au}$ mineralization contain $\mathrm{Ag}$ - and Bi-tellurides and selenides in association with minerals of other elements such as Au, Ga, Ge, In, Sn, and As [44,45,48-50].

\subsection{The Assarel Porphyry Copper Deposit}

The Assarel porphyry copper deposit forms part of the Assarel-Medet ore field in the central part of the Panagyurishte district (Figures 2B and 3). The deposit has been actively mined since 1976 and a pre-mining resource is estimated to be ca. $390 \mathrm{Mt}$, with average grades of $0.41 \mathrm{wt} \% \mathrm{Cu}, 0.12 \mathrm{~g} / \mathrm{t}$ $\mathrm{Au}$, and $<20 \mathrm{ppm} \mathrm{Mo}[51,52]$. The precious metal contents of the flotation concentrate containing $27.9 \mathrm{wt} \% \mathrm{Cu}$ are $54 \mathrm{ppb} \mathrm{Pd}, 14 \mathrm{ppb} \mathrm{Pt}$, and $4800 \mathrm{ppb} \mathrm{Au}$ [53]. Porphyry copper mineralization at Assarel is mainly hosted in dioritic to granitic subvolcanic and comagmatic andesitic volcanic rocks and comprises both vein-hosted and disseminated mineralization styles. Chalcopyrite and pyrite are the main ore minerals in the primary ore, while secondary covellite, chalcocite, and bornite are the main ore minerals in the supergene enrichment zone from the upper level of the deposit $[28,30]$.

The Assarel deposit (ca. $91 \mathrm{Ma}$ ) [29] forms part of the Assarel-Medet magmatic structure that consists of the Assarel stratovolcano, and numerous diorite and granodiorite intrusive bodies and dykes, which intruded Late Cretaceous volcanic rocks and the Precambrian-Paleozoic basement $[37,45,46]$ (Figure 3A,B). The Assarel stratovolcano is made up dominantly of andesite, with transitions to latite, basaltic andesite, quartz-andesite, and dacite $[28,38]$. The presence of pyrrhotite and chalcopyrite as inclusions in hornblende and pyroxene phenocrysts of comagmatic volcanic rocks from Assarel has been interpreted as evidence of the high $\mathrm{S}$ content of the magma that generated the Assarel intrusion [38,54,55]. Radial and concentric joints and faults and block dislocations were developed within the Assarel stratovolcano after the eruptive stage, which favored the subsequent ascent of magma and hydrothermal fluids [28].

The Assarel deposit is genetically related to the magmas intruded both in their comagmatic volcanic rocks of the Assarel stratovolcano and in the Precambrian-Paleozoic basement [28,37,45]. Zartova et al. [38] and Nedialkov et al. [54,55] mention the following petrographic types of Late Cretaceous rocks within the Assarel intrusive complex, related to three pulses: (1) fine to medium quartz-diorite to quartz-monzodiorite and quartz-monzonite porphyries; (2) fine to medium grained porphyritic quartz-diorite, quartz-monzonite to granodiorite; and (3) granite porphyry (syn- to post-ore).

The main ore body at Assarel consists of a cone-shaped stockwork [37,45,47]. According to Strashimirov et al. [37], the ore deposit at Assarel shows typical porphyry copper features at depth, with an overprint of high-sulfidation epithermal mineralization at shallower levels, indicated by the occurrence of minerals such as enargite, goldfieldite, calaverite, hessite, tetradymite, aikinite, wittichenite, and arsenosulvanite. The copper grade shows the highest values in the central part of the deposit and gradually decreases towards the periphery [37,45,47]. The Assarel deposit preserved well-developed supergene oxidation and enrichment zones in its upper levels $[28,37,47]$. The quartz-magnetite-hematite assemblage commonly observed at Elatsite has a minor extent at Assarel $[28,37]$. In contrast, the quartz-pyrite-chalcopyrite assemblage is developed mainly in the apical parts of the Assarel intrusion and is less common in the hydrothermally altered volcanic rocks [37], while the quartz-pyrite association is well represented in the peripheral and higher parts of the deposit [47]. The quartz-molybdenite association is very rare in Assarel, occurring mainly in the central and southeastern parts of the deposit $[37,47]$. On the other hand, the assemblage of 
quartz-sphalerite-galena is typical for the peripheral parts of the deposit marking the terminal stage of the mineralization [47].

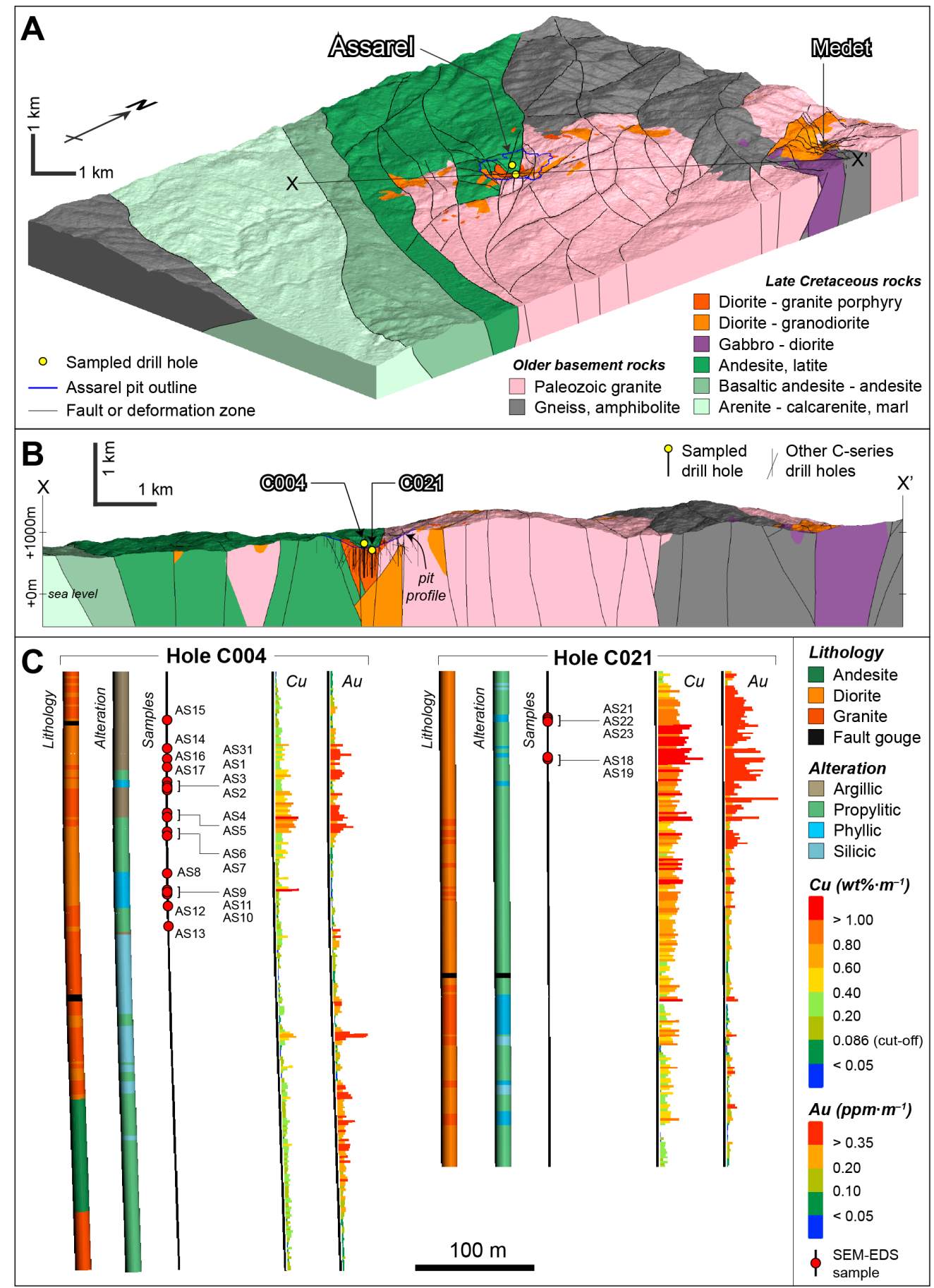

Figure 3. (A) 3D geological model of the Assarel-Medet area, looking to the northwest (partly based on Iliev and Katckov [55]). Outline of the Assarel pit is highlighted. (B) NE-SW cross-section through the Assarel-Medet area corresponding to profile line $\mathrm{X}-\mathrm{X}^{\prime}$ shown in A (note scale difference). Sampled drill holes C004 and C021 and other C-series drill holes also shown. Legend in (A) also applies to (B). (C) Schematic geological logs (looking to the NW) and $\mathrm{Cu}$ and Au grades for drill holes C004 and C021. The locations of 23 samples used for scanning electron microscopy-energy dispersive spectrometry (SEM-EDS) analysis also shown. 
The alteration patterns at Assarel are complex and probably resulted from the overlapping and superimposition of different types of alteration, which generated transitional types. Several authors $[28,37,45,51]$ distinguished a pre-ore sequence of hydrothermal alteration types (propylitic, propylitic-argillic, propylitic-sericitic, sericitic, sericitic-advanced argillic, and advanced argillic). Popov et al. [28,47] relate a pre-ore alteration sequence to the epithermal stages associated with the end of the effusive activity and the emplacement of small subvolcanic bodies and dikes. This was followed by the development of potassic and propylitic alteration related to porphyry copper mineralization. Potassic alteration is mentioned in literature as scarce relics being largely obliterated by subsequent sericitization and argillization [37,51].

Veinlets filled with K-feldspar and biotite within the propylitic zone from Assarel are mentioned by Hikov [51]. Propylitic alteration is well developed in the lower and peripheral parts of the deposit, also affecting the granodioritic porphyry rocks, Paleozoic granite, and Late Cretaceous volcanic rocks [46,51]. Sericitic and transitional sericitic-propylitic alteration are commonly associated with the main mineralization stage, which produced the assemblage quartz + chalcopyrite \pm pyrite $[36,46]$.

Strashimirov et al. [30,37] consider sericitization and argillization as being epithermal in character and the effect of a subsequent (late) stage of alteration. Advanced argillization is well developed in the upper parts of the deposit, particularly in the northwest part, inducing the formation of silica-rich rocks, named "secondary quartzite" by some authors [28,46,51].

\section{Materials and Methods}

A set of 24 samples were collected from three drill cores that intersect porphyry copper mineralization at Assarel. Eighteen samples were collected from drill hole C004, five samples from drill hole C021, and one sample from drill hole C030. The samples were selected based on the results of exploration assay data and thus were anticipated to contain $\mathrm{Cu}$ - and $\mathrm{Au}$-bearing minerals. The main petrographic characteristics and mineralization of these samples are summarized in Table S1 of the Supplementary Material, while the location of drill holes C004 and C021 and the position of the samples along these holes are illustrated in Figure 3.

The mineralogy and petrography of the samples were determined by means of optical microscopy at the Geological Institute of Romania (IGR), Bucharest, using an Axio Imager.A2m (Carl Zeiss Microscopy GmbH, Jena, Germany) petrographic microscope equipped with an AxioCam ICc5 (Carl Zeiss Microscopy GmbH, Jena, Germany) digital camera. The 24 metal-rich samples were also investigated by electron microscopy at IGR using a Hitachi Tabletop SEM Microscope TM3030 (Hitachi Ltd., Tokyo, Japan) equipped with a Bruker Quantax75 (Bruker Nano GmbH, Berlin, Germany) Energy Dispersive X-ray Spectrometer (EDS). Eight of the samples investigated in Bucharest were also studied by SEM-EDS at the Department of Earth, Environment and Planetary Science, Rice University, Houston, using a JEOL JXA 8530F Hyperprobe (JEOL Ltd., Tokyo, Japan) equipped with a field emission assisted thermo-ionic (Schottky) emitter, five Wavelength Dispersive Spectrometers (WDS) and one JEOL Silicon Drift (SD) (JEOL Ltd., Tokyo, Japan) X-ray EDS Detector with $10 \mathrm{~mm}^{2}$ active area and $133 \mathrm{eV}$ resolution. An acceleration voltage of $15 \mathrm{kV}$ was employed with both instruments.

\section{Results}

\subsection{Ore and Hydrothermal Alteration Mineralogy}

Copper mineralization in the investigated ore samples mainly occurs as disseminated and stockwork/veining styles in hydrothermally altered volcanic and subvolcanic host-rocks and basement Paleozoic granite. From the petrography results, four key assemblages comprising major ore and gangue minerals can be grouped based on their interpreted paragenesis and a common association with distinct types of host rock alteration. Mineral assemblage types described in this paper represent petrographically characteristic groupings of two or more hydrothermal minerals formed under either equilibrium or disequilibrium conditions, with key constituent minerals listed in decreasing relative 
abundance (e.g. Gifkins et al. [56]). Where observed, evidence for paragenetic disequilibrium (e.g., overprinting, replacement) is given and discussed. We identified the following types of alteration in the samples we investigated: propylitic, sericitic, sericitic-chloritic, and argillic. Alteration type terminology (e.g., propylitic, sericitic, chloritic, argillic) follows that presented by Thompson and Thompson [57]. Silicification is very likely in most samples but, excepting the case of quartz-rich veinlets, we could not discriminate clearly between the silica from the original rocks (frequently, granodiorite) and the silica added by the hydrothermal processes. Overlapping of these alteration types generates transitional facies.

\subsubsection{Chalcopyrite-Pyrite-Magnetite \pm Bornite (CPM) Assemblage Associated with Propylitic Alteration}

The chalcopyrite-pyrite-magnetite \pm bornite (CPM) assemblage consists of fine-grained (ca. $0.1-0.5 \mathrm{~mm}$ ) chalcopyrite and subordinate magnetite and pyrite that form impregnations and veinlets (less than $1 \mathrm{~mm}$ across) in porphyritic rocks affected by moderate to intense propylitic alteration. This assemblage can be considered a sub-type of the quartz-pyrite-chalcopyrite assemblage identified by Strashimirov et al. $[30,37]$. Magnetite is partly replaced by hematite and can contain inclusions of chalcopyrite and bornite. In two samples (AS6 and AS7, Table S1), secondary covellite and bornite are formed on chalcopyrite.

Plagioclase phenocrysts in porphyritic wall rocks are partly replaced by epidote, albite, sericite and clay minerals (Figure 4a). There is no evidence of previous potassic alteration of feldspars. Chlorite, epidote and opaque minerals totally replace mafic mineral phenocrysts (probably amphibole) where present (Figure $4 \mathrm{~b}$ ). Chlorite, in association with rutile and titanite, also occurs as disseminated grains in the groundmass or along the margins of mineralized fissures and quartz veinlets. Clusters of minute rutile, thorite, zircon, apatite, and monazite were also found in the groundmass of altered porphyritic wall rock. Frequently, monazite also occur as inclusions in apatite.

\subsubsection{Chalcopyrite-Pyrite-Hematite ( $\mathrm{CPH}$ ) Assemblage Associated with Sericitic-Chloritic Alteration}

This assemblage is well developed in quartz-rich rocks from drill hole C021 affected by relatively intense sericitic-chloritic alteration. The host rock is characterized by the complete transformation and obliteration of magmatic textures, resulting in a groundmass dominated by quartz and sericite, with variable chlorite. Chlorite-sericite intergrowths also infill cracks and vuggs (Figure 5a). This alteration type probably is referred to as propylitic-sericitic alteration (chlorite + illite + quartz + pyrite) by Strashimirov et al. [30,37] at Assarel. We define this alteration as sericitic-chloritic, considering that most key minerals of propylitic alteration type (e.g., epidote, albite, calcite) are not found in these rocks. The mineralization consists of chalcopyrite, pyrite and lamellar hematite, frequently being intergrown with chlorite and sericite and filling veinlets and cracks (Figures $4 \mathrm{c}$ and $5 \mathrm{~b}, \mathrm{c}$ ). Chalcopyrite replaces and surrounds hematite (Figure $5 \mathrm{c}$ ), forming rims and filling the cracks of hematite. Chalcopyrite replaces or engulfs pyrite (Figures $5 \mathrm{~b}$ and $6 \mathrm{a}, \mathrm{d}-\mathrm{i}$ ). Pyrite has a poikilitic microtexture, with numerous inclusions of quartz, rutile, albite, muscovite and sulfide minerals (chalcopyrite, bornite, and galena). Most of the rare minerals described in this paper (e.g., gold, idaite, wittichenite, merenskyite, greenokite) are hosted by pyrite in this assemblage, as micrometer-sized inclusions or occur at the contact of pyrite with chalcopyrite (e.g., naumannite, clausthalite, hessite; Figure 6c-1). It also can be considered as a subtype of the quartz-pyrite-chalcopyrite assemblage identified by Strashimirov et al. $[37,46]$ and thus may be paragenetically related to the CPM assemblage described above.

\subsubsection{Fine-Grained Pyrite-Chalcopyrite (PC) Assemblage Associated with Argillic Alteration}

This assemblage is found in rocks with relatively intense argillic alteration, dominated by clay minerals (Figure $4 \mathrm{~d}$ ). The samples of rocks with argillic alteration (sometimes overprinting sericitic alteration) commonly contain fine-grained pyrite and chalcopyrite $(<0.2 \mathrm{~mm})$, without magnetite or hematite (Figure $5 \mathrm{~d}$ ). In these samples, primary igneous features of the host rock are typically completely obliterated. 

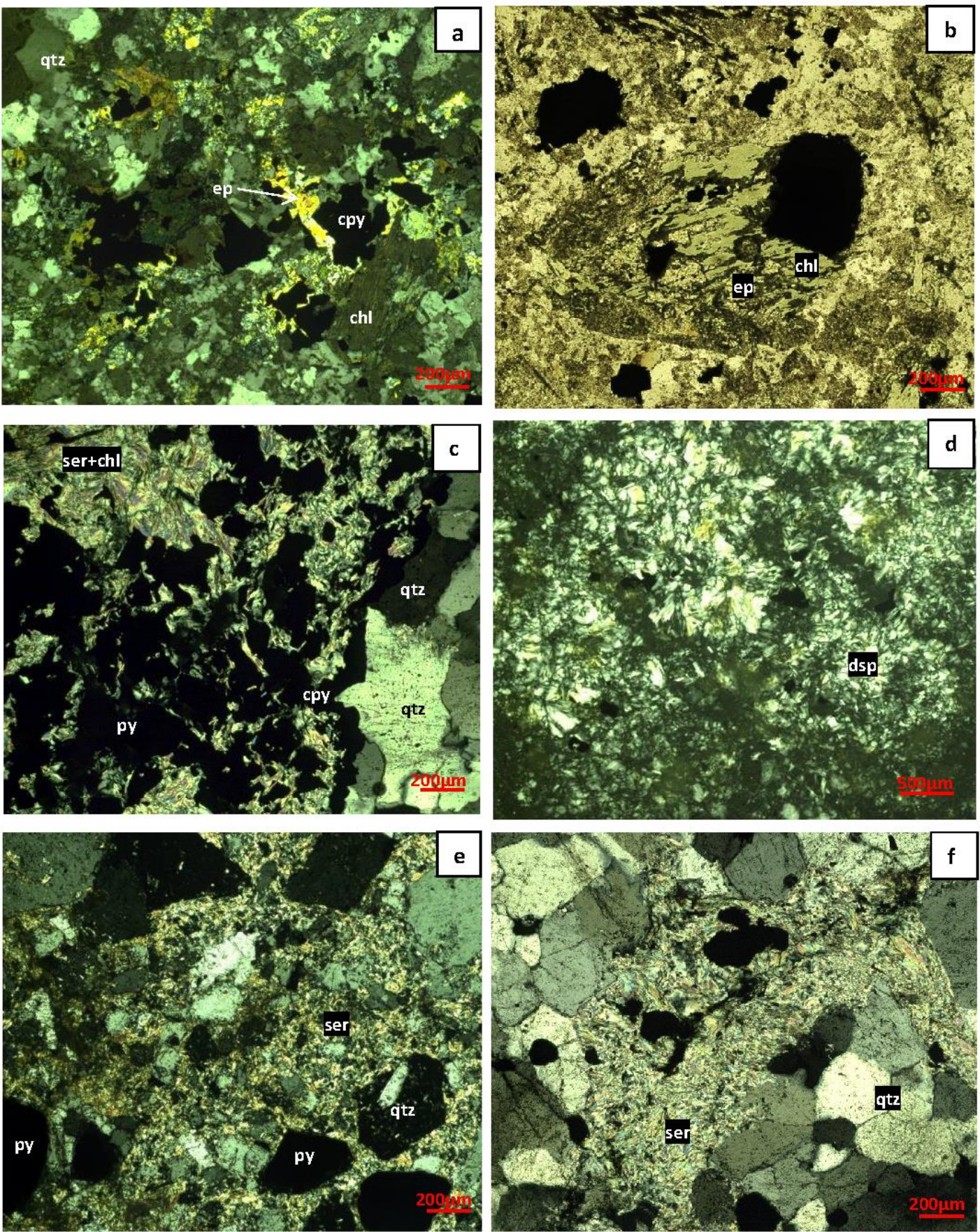

Figure 4. Images of hydrothermal alteration mineral assemblages from Assarel. (a) Rock with propylitic alteration: groundmass made up of quartz, albite, epidote, sericite and chlorite (sample AS6). (b) Mafic phenocryst (probably amphibole) substituted by chlorite and epidote in a rock with propylitic alteration (sample AS5). (c) Intergrowth of calcopyrite, pyrite, sericite, and chlorite in a rock with sericitic-chloritic alteration (sample AS18). (d) Pervasive argillic alteration with diaspore, illite, and fine-grained pyrite mineralization (sample AS14). (e) Disseminated pyrite in a rock with sericitic alteration (sample AS30). (f) Sericitic alteration, with sericite filling a vugg in a quartz-rich rock (sample AS30). Transmitted light. (a,c-f)—crossed nicols; (b)—parallel nicols. Abbreviations: cpy-chalcopyrite, chl—chlorite, dsp—diaspore, ep—epidote, py—pyrite, qtz—quartz, ser—sericite. 

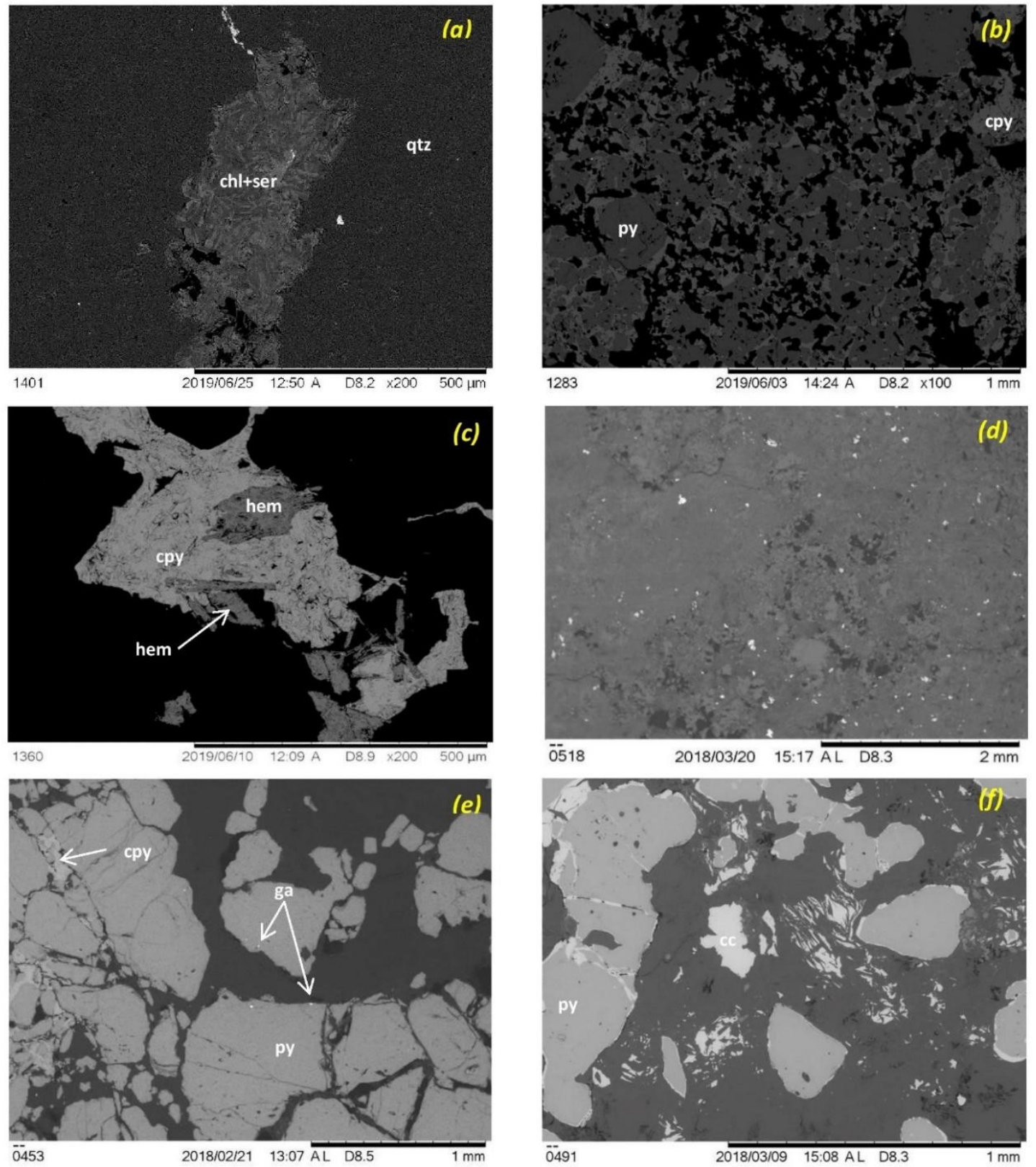

Figure 5. Back scattered electron images of mineral assemblages from Assarel. (a) Chlorite (dark gray) and sericite (gray) intergrowths in the vugg (CPH assemblage, sample AS21). (b) Pyrite surrounded by chalcopyrite in a rock with sericitic-chloritic alteration (CPH assemblage, sample AS18). (c) Euhedral hematite (dark gray) replaced and overgrown by chalcopyrite (light gray) in a rock with sericitic-chloritic alteration (CPH assemblage, sample AS21). (d) Fine pyrite (white grains) disseminated in rock with argillic alteration (PC assemblage, sample AS4). (e) Aggregate of coarse pyrite grains in quartz-pyrite assemblage. Galena inclusions (white dots) occur in the peripheral zone of pyrite grains (QP assemblage, sample AS3). (f) Supergene alteration of pyrite (gray), by substitution with chalcocite (light grey), (QP assemblage, sample AS30); Abbreviations: chl—chlorite, cpy—chalcopyrite, cc—chalcocite, ga—galena, hem-hematite, py—pyrite, qtz-quartz, ser—sericite.

\subsubsection{Quartz-Pyrite \pm Chalcopyrite (QP) Assemblage Associated with Sericitic Alteration}

A distinct quartz-pyrite \pm chalcopyrite assemblage occurs in some quartz-rich sericitized rock samples. In contrast to PC assemblage, this assemblage is characterized by abundant disseminated euhedral pyrite grains or as well-developed aggregates (Figure 5e) and pyrite veins. Chalcopyrite 
has a minor contribution (up to $10 \%$ of the sulfides), as small grains $(<0.5 \mathrm{~mm}$ ) disseminated in the groundmass or filling the space between pyrite grains (Figure 5e).
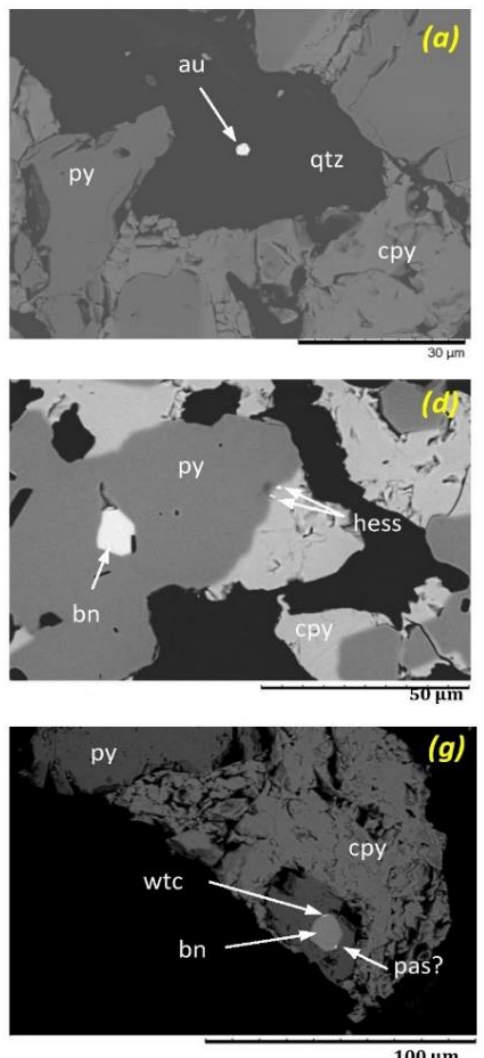

g)
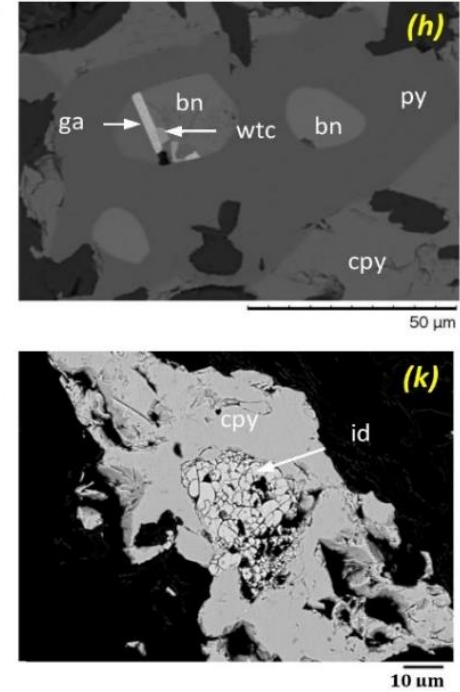

(b)

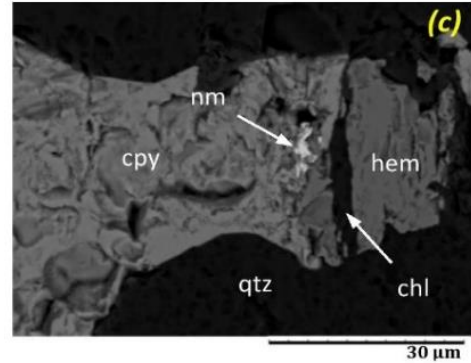

(e)
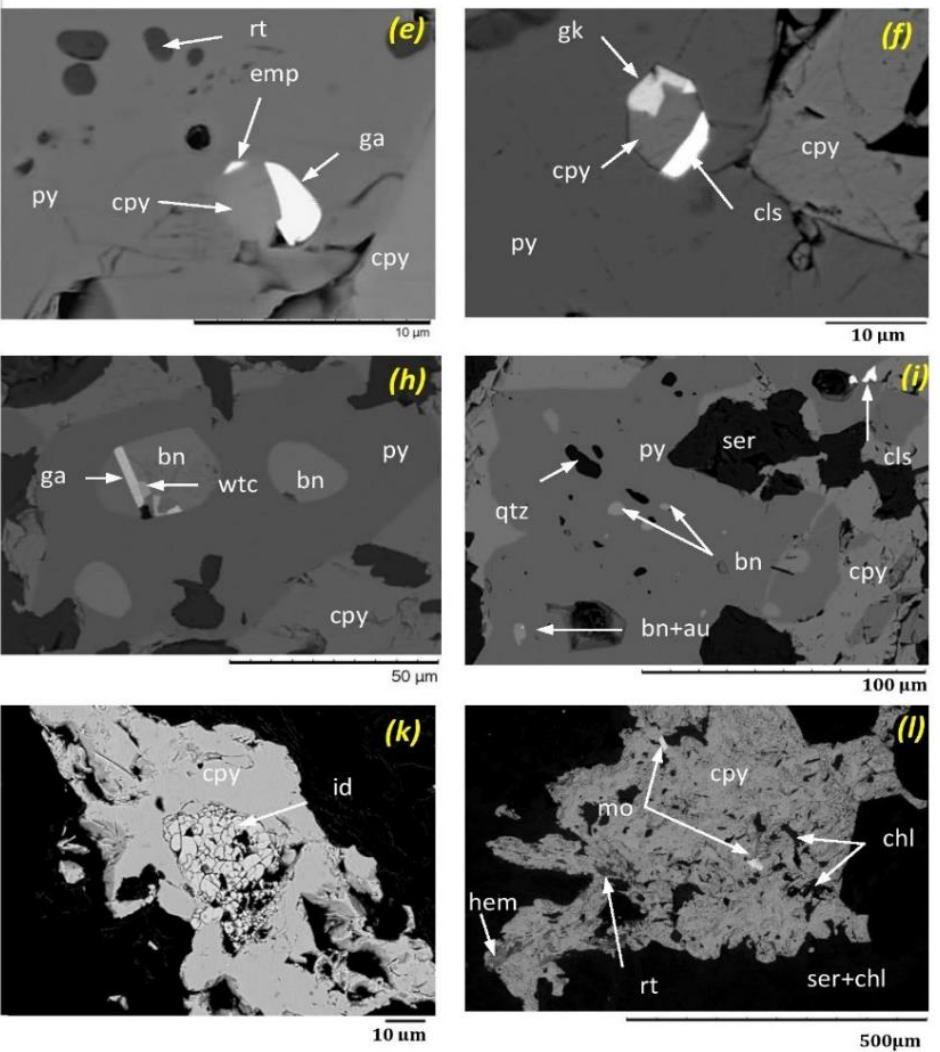

Figure 6. Back-scattered electron images of trace minerals from Assarel copper deposit. (a) Gold in quartz (CPH assemblage, sample AS18) (b) dendritic acanthite in QP assemblage (sample AS2); (c) naumannite in chalcopyrite in association with hematite and chlorite (CPH assemblage, sample AS21); (d) hessite occurring at the limit between pyrite and chalcopyrite (CPH assemblage, sample AS18); (e-h) polymineral inclusions hosted by pyrite in CPH assemblage (sample AS18); (i) chalcopyrite and pyrite mineralization from $\mathrm{CPH}$ assemblage with bornite, gold and quartz inclusions in pyrite and clausthalite grains at the margin of chalcopyrite (sample AS18); (j) numerous bismuthinite inclusions (white dots) in euhedral pyrite from QP assemblage (sample AS2); (k) idaite on chalcopyrite (CPM assemblage, sample AS6); (1) molybdenite and chlorite crystals in chalcopyrite in association with rutile, hematite, sericite and chlorite infilling vugg spaces in the CPH assemblage (sample AS21). Abbreviations: ach-acanthite, bn-bornite, chl—chlorite, cls—clausthalite, cpy-chalcopyrite, emp-empressite, ga-galena, gk-greenockite, au—native gold/electrum, hem-hematite, hess-hessite, id-idaite, mo-molybdenite, nm—naumannite, pas?-probably pasavaite, py—pyrite, qtz-quartz, rt—rutile, ser-sericite, wtc—wittichenite.

Pyrite hosts inclusions of chalcopyrite, bornite, covellite, galena, and Bi- and Ag-bearing minerals (Figure 6j). In general, these inclusions are distributed in the peripheral parts of pyrite grains (Figure 5e). Although the host rock is mainly made up of quartz and sericite (Figure 4e,f), a clay-rich argillic 
overprint is also locally present. Primary igneous texture of the host rock is typically completely obliterated. In one sample (AS30), pyrite and chalcopyrite are totally or partially replaced by secondary covellite (Figure $5 \mathrm{f}$ ).

\subsection{Mode of Occurrence of Precious Metals and Associated Minerals}

SEM-EDS investigations outlined the presence of mineral species of $\mathrm{Au}, \mathrm{Ag}$ and $\mathrm{Pd}$, associated with $\mathrm{Ni}, \mathrm{Cu}, \mathrm{Bi}$ or $\mathrm{Cd}$-bearing sulfides, selenides or tellurides. All these minerals occur as tiny grains $(<1-10 \mu \mathrm{m})$ included by the main sulfides or, more rarely, disseminated in the groundmass. Among these, there are native gold, electrum, auricupride, tetra-auricupride, nagyagite, native silver, acanthite, hessite, empressite, naumannite, merenskyite, bismuthinite, aikinite, wittichenite, greenokite, and clausthalite (see Table S1). These minerals occur in all types of mineralization described above. The distribution of these minerals related to the main mineral assemblages and alteration types of the host rock is given in the Table S1. Many of the trace minerals mentioned in this section occur as grains less than $1 \mu \mathrm{m}$ in size. Because of this, their chemical composition could not be constrained by the calculation of an average of several measured EDS points.

\subsubsection{Gold Minerals}

Native gold $(\mathrm{Au})$ is relatively common in the studied samples. Gold grains were found as inclusions in chalcopyrite and pyrite, or as flakes in the groundmass in all of the mineral assemblages described above (Figure 6a,i). Gold grains commonly show $\mathrm{Ag}$ concentrations up to $18 \mathrm{wt} \%$, occasionally showing electrum composition ( $24-33 \mathrm{wt} \% \mathrm{Ag}$ ) in rocks affected by propylitic alteration. So far, no correlation could be remarked between the $\mathrm{Ag}$ content of gold grains and the host mineral or the associated mineral assemblage. Very small $(<1 \mu \mathrm{m})$ auricupride $\left(\mathrm{Cu}_{3} \mathrm{Au}\right)$ and nagyágite $\left[(\mathrm{Te}, \mathrm{Au}) \mathrm{Pb}(\mathrm{Pb}, \mathrm{Sb}) \mathrm{S}_{2}\right]$ grains were found in the groundmass of some samples with sericitic-chloritic alteration, while micrometer-sized grains of tetra-auricupride $(\mathrm{AuCu})$ was found in the groundmass of the propylitic and sericitic-chloritic altered rocks. The EDS spectrum of nagyagite is given in Figure 7a.

\subsubsection{Silver Minerals}

In the copper mineralization at Assarel, silver occurs as native silver $(\mathrm{Ag})$, acanthite $\left(\mathrm{Ag}_{2} \mathrm{~S}\right)$, naummanite $\left(\mathrm{Ag}_{2} \mathrm{Se}\right)$, hessite $\left(\mathrm{Ag}_{2} \mathrm{Te}\right)$, and empressite ( $\left.\mathrm{AgTe}\right)$. In this study, native silver and acanthite were found as disseminated micrometer-sized grains in the groundmass of host rocks affected by quartz-sericitic and sericitic-chloritic alteration (Figure 6b). The Ag telluride and selenide species are spatially associated with the $\mathrm{CPH}$ assemblage in rocks with sericite-chlorite alteration, with naummanite occurring within or at the periphery of chalcopyrite grains (Figure 6c), while hessite and empressite were identified as components of a complex inclusion in poikilitic pyrite and as small, round inclusions in chalcopyrite (Figure $6 \mathrm{~d}, \mathrm{e})$. Hessite was also identified as small grains $(<3 \mu \mathrm{m})$ within pyrite and in the groundmass of rocks affected by sericitic alteration (QP assemblage).

\subsubsection{Platinum-Group Minerals}

Two tiny grains $(<1 \mu \mathrm{m}$ in size) of Pd minerals were identified in our samples, in association with the $\mathrm{CPH}$ assemblage. Merenskyite $\left(\mathrm{PdTe}_{2}\right)$ was identified as an inclusion in pyrite. A second $\mathrm{Pd}$ mineral was identified as a component of a polymineralic inclusion in pyrite, together with bornite and wittichenite (Figure 6g). Its composition includes $\mathrm{Pb}, \mathrm{Pd}$ and $\mathrm{Te}$, like in pasavaite $\left(\mathrm{Pb}_{3} \mathrm{Pd}_{2} \mathrm{Te}_{2}\right)$, but quantification of corresponding EDS data produced elemental ratios different from those in pasavaite. The EDS compositional spectra of Pd minerals are given in Figure 7b,c. 

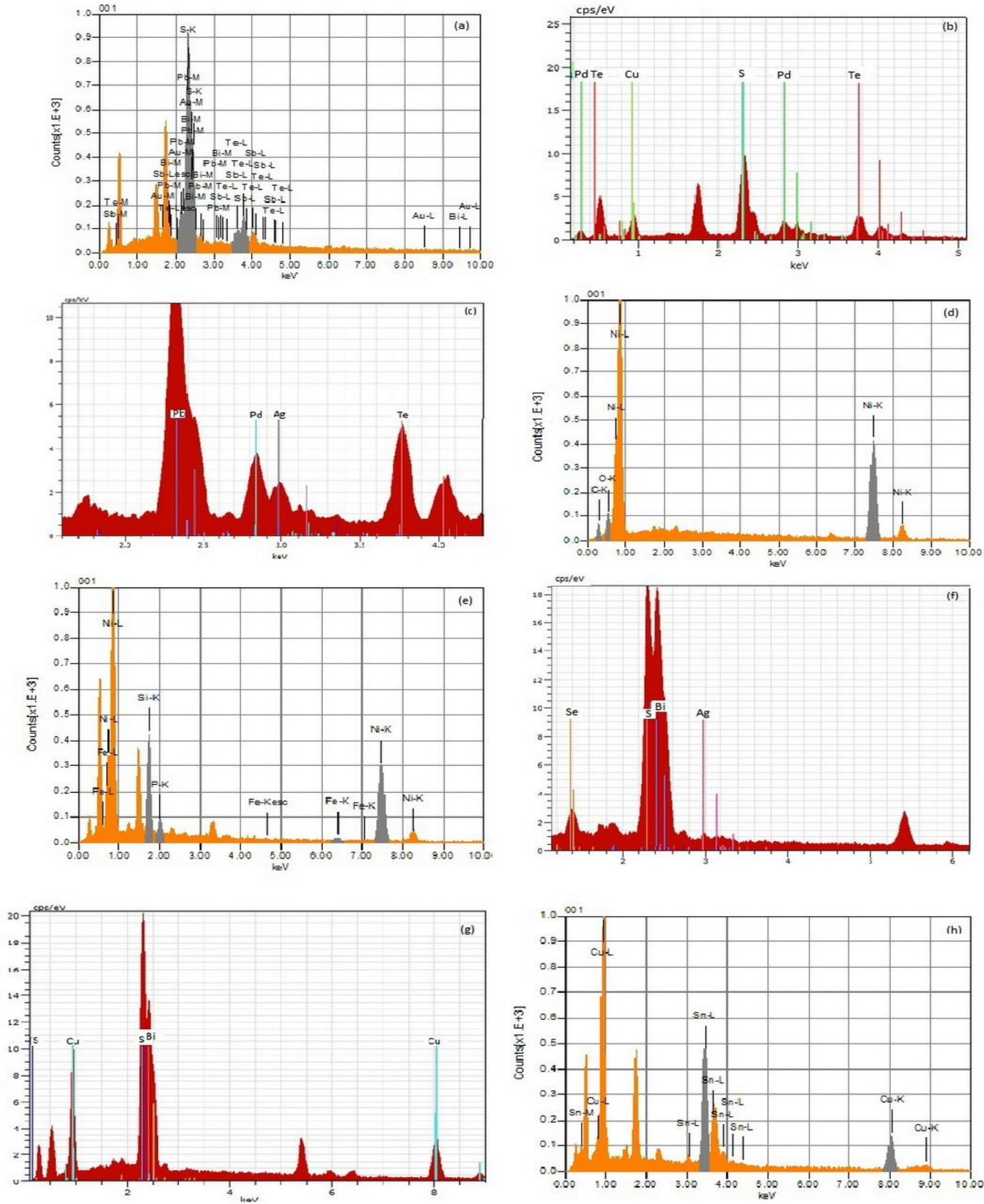

Figure 7. SEM-EDS spectra of several rare minerals and metals found in the samples from Assarel mine. (a) nagyagite; (b) merenskyite (Fe and S are from host pyrite); (c) pasavaite (?); (d) native nickel; (e) perryite (?); (f) bismuthinite; (g) wittichenite, (h) sorosite. Spectra (a,d,e,h) were obtained at Rice University (grey peaks are main peaks, used for quantification, while orange peaks are secondary peaks); spectra (b,c,f,g) were obtained at the Geological Institute of Romania.

\subsubsection{Nickel Minerals}

Native nickel (Ni) was found as grains (up to $20 \mu \mathrm{m}$ in size) in the silicate rock groundmass of sericitic and sericitic-chloritic altered rocks. Another Ni mineral was identified in 3 grains $(<1 \mu \mathrm{m}$ in size) from two samples (AS11, AS23; Table S1). These grains appear to be made of the same elements as those of perryite $\left[(\mathrm{Ni}, \mathrm{Fe})_{8}(\mathrm{Si}, \mathrm{P})_{3}\right]$ but with a large variability of $\mathrm{Ni}$ and $\mathrm{Si}$ contents, probably because of their small size, which did not allow for accurate compositional measurements. This postulated perryite 
occurs in association with quartz and sericite from rocks with mainly sericitic-chloritic alteration. EDS spectra of native nickel and perryite (?) are given in Figure 7d,e.

\subsubsection{Bismuth Minerals}

Bismuthinite $\left(\mathrm{Bi}_{2} \mathrm{~S}_{3}\right)$ and wittichenite $\left(\mathrm{Cu}_{3} \mathrm{BiS}_{3}\right)$ are the only bismuth minerals identified in this study. Bismuthinite occurs as small inclusions $(<1 \mu \mathrm{m})$ in pyrite (Figure 6j) from the QP assemblage and as tiny grains in the groundmass in all types of investigated host rock. Wittichenite was found only in two samples (AS2, AS18; Table S1) as a component of polymineral inclusions in pyrite. In one of the samples (AS18), bearing the $\mathrm{CPH}$ assemblage, wittichenite is included in pyrite together with bornite and $\mathrm{Pd}-\mathrm{Pb}$ telluride and with bornite and galena (Figure 6g,h). In AS2 sample, containing the QP assemblage, wittichenite occurs in pyrite together with covellite and with galena. EDS spectra of bismuthinite and wittichenite are given in Figure 7f,g.

\subsubsection{Other Minerals}

Clausthalite (PbSe) occurs along pyrite-chalcopyrite boundaries or is enclosed by chalcopyrite from the $\mathrm{CPH}$ assemblage (Figure 6i). Also, clausthalite is a component of polymineralic inclusions in poikilitic pyrite from the $\mathrm{CPH}$ assemblage, where it is associated with idaite or with chalcopyrite, greenockite (CdS) and albite (Figure 6f). Clausthalite is found also as inclusion in chalcopyrite and in the groundmass of propylitic altered rocks. Idaite $\left(\mathrm{Cu}_{5} \mathrm{FeS}_{6}\right)$ is present as relics in chalcopyrite (Figure 6k) and as inclusions in pyrite from the CPM and $\mathrm{CPH}$ assemblages. As a component of a polymineralic inclusion in pyrite, idaite was found together with clausthalite and native gold. Sorosite $\left[\mathrm{Cu}_{1+\mathrm{x}}(\mathrm{Sn}, \mathrm{Sb})\right.$, where $\left.0.1 \leq \mathrm{x} \leq 0.2\right]$ and other copper-tin alloys (up to $39 \mathrm{wt} \% \mathrm{Sn}$ ) were also identified as singular grains, up to $4 \mu \mathrm{m}$ in size, occurring in the groundmass of rocks affected by propylitic and sericitic-chloritic alteration, while native copper $(\mathrm{Cu})$ is present in the groundmass of rocks regardless of the alteration type One EDS spectrum of sorosite is given in Figure 7h. Molybdenite was found in association with chalcopyrite (Figure 61), as inclusion in pyrite, and in the groundmass of most types of mineral assemblages (CPM, $\mathrm{CPH}$ and $\mathrm{CP}$ ) described above. Accessory minerals (rutile, titanite, zircon, thorianite, apatite, monazite, xenotime, barite, witherite) occur in all types of rock regardless of their alteration. Monazite was frequently identified as numerous micrometer-sized grains in the altered groundmass, but also as inclusions in rutile, apatite, quartz, pyrite and chalcopyrite.

\section{Discussion}

Assarel is one of the largest porphyry copper deposits in Europe [58] and located relatively close to two other large porphyry copper deposits at Elatsite and Medet (Figure 2). Although these neighboring deposits show common geological features with those at Assarel (e.g., a genetic association with Late Cretaceous intermediate to felsic porphyritic intrusions; vein-hosted $\mathrm{Cu}$-sulfide mineralization), several unique geological and mineralogical features occur at Assarel that differentiate it from the other systems. For example, unlike the Elatsite and Medet deposits which are linked to intrusions wholly emplaced within the Precambrian-Paleozoic basement, $\mathrm{Cu}$ mineralization at Assarel is related to subvolcanic intrusions emplaced partly within a comagmatic volcanic edifice (i.e., the Assarel stratovolcano [27,37,45]). A well-developed epithermal imprint at Assarel, as indicated by the occurrence of enargite, goldfieldite, calaverite, hessite, tetradymite, aikinite, wittichenite, and arsenosulvanite, is also a feature specific to this deposit. Considering the various porphyry and epithermal ore mineral assemblages in the district, the paragenetically early/deeper quartz-magnetite-hematite ( \pm bornite-chalcopyrite) assemblage has a minor extent at Assarel if compared with Elatsite and Medet [28,37,47], while the quartz-molybdenite association is also uncommon.

A multistage evolution and superimposition of successive hydrothermal alteration and mineralization stages are common features of porphyry copper-type deposits worldwide $[1,59]$. The Assarel deposit displays similar overlapping or superimposed hydrothermal effects, as highlighted 
by previous mineralogical and geochronological research $[37,41,42,46,51]$. Here, we discuss some specific aspects of this complex hydrothermal history with a focus on the setting of precious metals ( $\mathrm{Au}$, Ag, PGEs) and related minerals, their relationship to the observed hydrothermal mineral assemblages, and their implications in terms of changes to the ore-forming conditions of the porphyry system. The potential impact of our findings on the technical development and application of X-MINE drill core scanning technology is also discussed.

\subsection{Mineralization and Alteration}

At Assarel, multiple hydrothermal events formed several identifiable ore and alteration mineral assemblages that partly overlap in both space and time. The mineralogy of several of our samples suggests that the relatively common pyrite-chalcopyrite ore assemblage (representing the main mineralization stage) may have been superimposed upon an earlier formed and more regionally distributed magnetite-hematite \pm chalcopyrite \pm bornite assemblage as identified at other near-by porphyry deposits [28,37,43-46]. Alternatively, our petrographic results suggest magnetite and hematite commonly do not occur together as primary phases at Assarel, suggesting a post-ore oxidation relationship for these iron oxide phases. In some samples from drill hole C004 (Table S1), magnetite ( \pm chalcopyrite \pm bornite inclusions) is the only primary iron oxide phase, with hematite occurring due to martitization.

In general, the samples with chalcopyrite, pyrite and magnetite come from wall rocks affected by identifiable propylitic (chlorite-albite-epidote-sericite) alteration. Previous research at Assarel [37,46] relates potassic alteration with the propylitic alteration, both seen as relatively early alteration stages, as compared with the sericitization, which overprinted them. A similar correlation was reported from Medet [37]. At Elatsite, Tarkian et al. [23] considered the earliest mineralization (magnetite-bornite-chalcopyrite) to be associated with potassic-propylitic alteration. The mineralogy of our samples with propylitic alteration are consistent with a similar mineralization-alteration coupling at Assarel, although the magnetite-chalcopyrite \pm bornite assemblage at Assarel is less common compared to Elatsite $[37,46]$. A particular geochemical signature with $\mathrm{Au}, \mathrm{Ag}$, Te, Se, PGE, Co, and Ni characterizes the magnetite-bornite-chalcopyrite assemblage of Elatsite [30], inducing the occurrence minerals of $\mathrm{Au}$, $\mathrm{Ag}, \mathrm{Te}, \mathrm{Se}$, and Pd (as native gold, hessite, clausthalite, and merenskyite) as inclusions in bornite and chalcopyrite [23].

The chalcopyrite-pyrite mineralization is typically associated with sericitic alteration both at Assarel [37,46] and Elatsite [23]. For the samples from sericite-chlorite altered rocks containing the chalcopyrite-pyrite mineralization (CPH assemblage), hematite (commonly, abundant) is the main iron oxide phase, typically occurring as euhedral, prismatic blades intergrown with groundmass phyllosilicates. Hematite from these rocks is partly replaced by chalcopyrite (Figure 5c), which supports the earlier deposition of hematite with respect to chalcopyrite. Although the bulk of these samples comprise quartz, sericite, and chlorite, the presence of chlorite could be ascribed to earlier developed propylitic alteration or to the transformation of biotite linked to an early phase of potassic alteration. Thus, the $\mathrm{CPH}$ assemblage associated with sericitic-chloritic alteration likely post-dates or overprints the earlier magnetite-bearing chalcopyrite-pyrite \pm bornite assemblage (associated with propylitic alteration) and may represent a distinct episode of fluid flow and mineralization, consistent with a multistage hydrothermal evolution.

\subsection{Precious Metals and Aspects of Ore-Forming Conditions}

Based on the petrographic results, precious metals at Assarel occur in their native state ( $\mathrm{Au}$ and $\mathrm{Ag}$ ), as tellurides (Ag and PGE), as sulfosalts (Au) or as selenides (Ag) in the CPM and $\mathrm{CPH}$ mineralization associated with propylitic and sericitic-chloritic alteration, respectively. In several instances, precious metal-bearing minerals occur within oblate, polymineral inclusions hosted by pyrite grains. Such composite inclusions can contain various mineral associations such as galena-hessite-chalcopyrite, galena-clausthalite-chalcopyrite, clausthalite-greenokite-idaite, 
gold-bornite, bornite-galena-wittichenite, or wittichenite-bornite-Pd-Pb telluride (Figure $6 \mathrm{e}-\mathrm{i}$ ). The mineral paragenesis suggests polymineral inclusions formed from elements trapped by pyrite during its precipitation, followed by subsequent phase separation. If valid, mineral inclusions in pyrite from the $\mathrm{CPM}$ and $\mathrm{CPH}$ assemblages provide indications regarding the composition of precious metal-bearing mineralising fluids at Assarel. Additionally, the mineralogical variability of these composite inclusions suggests variation in the physico-chemical parameters of the mineralizing fluids. During the chalcopyrite-pyrite mineralization related to sericitic-chloritic alteration ( $\mathrm{CPH}$ assemblage), an increased $\mathrm{Cu}$ concentration in the hydrothermal fluids led to extensive chalcopyrite precipitation, which locally surrounds and/or replaces pyrite and hematite (Figure 5b,c and Figure $6 a, d-i)$. The presence of euhedral hematite partly replaced by main stage chalcopyrite also suggests more oxidized conditions preceded the main stage of $\mathrm{Cu} \pm \mathrm{Au}$ mineralization. Experimental work reported by Zhao et al. [60] indicates the replacement of hematite by chalcopyrite induced by hydrothermal fluids carrying $\mathrm{Cu}(\mathrm{I})$ complexes (as chloride) and hydrosulfide $\left(\mathrm{HS}^{-}\right)$at temperatures of $200-300^{\circ} \mathrm{C}$ and near neutral $\mathrm{pH}$ of hydrothermal solutions. This replacement occurs with a significant increase of volume; as an effect, hematite is not only replaced but also overgrown by chalcopyrite. A similar paragenetic relationship between hematite and chalcopyrite can be seen in the Assarel samples with sericitic-chloritic alteration. A mineralization temperature interval of ca. $200-300{ }^{\circ} \mathrm{C}$ is broadly consistent with previous fluid inclusion studies at Assarel [37,39], which indicate deposition of main stage pyrite-chalcopyrite from a fluid near $300^{\circ} \mathrm{C}$. Mineral relations in our samples indicate that $\mathrm{Ag}-\mathrm{Te}$ and $\mathrm{Ag}-\mathrm{Se}$ minerals and molybdenite $\left(\mathrm{MoS}_{2}\right)$ are also related to the $\mathrm{CPM}$ and $\mathrm{CPH}$ assemblages (i.e., with the main stage of $\mathrm{Cu}$ mineralization). The precipitation of tellurides is consistent with a change in redox conditions to a more neutral-reducing fluid, since Te is less soluble in reduced hydrothermal fluids [61].

\subsection{Implications of Precious Metals Distribution and for the Validation of 3D XRF-XCT Scanning}

In this study, standard optical microscopy and SEM-EDS have been used to identify minerals containing precious metals and determine their morphological character (size, form), relative abundances and paragenetic association with other hydrothermal minerals (i.e., $\mathrm{Cu}$-sulfides, pyrite, quartz/silicates). Previous research has remarked on the scarcity of native gold in the primary sulfide mineralization at Assarel $[28,37,46]$, in contrast with its common presence in parts of the upper supergene alteration zone $[37,46]$. Our petrographic results show the presence of native gold (sometimes allied with $\mathrm{Ag}$ or $\mathrm{Cu}$ ) occurring as part of the primary porphyry $\mathrm{Cu}$ mineralization, but only as very small $(<10 \mu \mathrm{m})$ included grains in sulfides, or disseminated flakes (Figure $6 \mathrm{a}, \mathrm{i})$. Overall, these results suggest $\mathrm{Au}$ is more widely distributed at Assarel than previously thought and not confined to upper level advanced argillic and supergene (gossan cap) alteration zones. This idea is generally supported by variable but locally elevated $(>0.35 \mathrm{ppm})$ Au concentrations in sub-vertical drill holes that extend downward into the Assarel ore body and intersect mainly propylitic-altered wall rocks (Figure 3). In contrast to Au, silver occurs mostly as tellurides, sulfides and selenides at Assarel, although, native Ag was also noted in sericitic-altered ore samples (Table S1). The paragenetic association between Ag minerals and the $\mathrm{CPH}$ assemblage, and its overall positive geochemical correlation with $\mathrm{Cu}$ [46] suggests $\mathrm{Ag}$ also has a relatively widespread distribution within the deposit like $\mathrm{Au}$. Two identified grains of rare Pd-bearing tellurides occurring in pyrite grains belonging to the $\mathrm{CPH}$ assemblage and associated with sericitic-chloritic alteration (Figures $6 \mathrm{~g}$ and $7 \mathrm{~b}, \mathrm{c}$ ) attest to some degree of PGE endowment at Assarel. Based on this limited observation, however, the precise extent of PGE mineralization remains uncertain and further work on the occurrence and distribution of PGE minerals is warranted.

The association between $\mathrm{Ag}$, $\mathrm{Pd}$, and, to a lesser degree, Au with Te-bearing minerals indicates the latter element could be used as a geochemical tracer of precious metals at Assarel. Likewise, Bi shows an affinity with pyrite associated with chalcopyrite, bornite, Ag and PGE minerals (Table S1; Figure 6g,h) and could therefore also be considered as a geochemical proxy for precious metals. Importantly, Bi is 
designated as a critical raw material by the European Union [62] and may also constitute a target commodity, depending on the economic profitability of its extraction. The presence of Te and Bi minerals in association with the precious metals at Assarel is consistent with the strong Bi-Te geochemical signature common for all types of metallic deposits in the BMMB [63] and with the potential use of Bi-Te-Se assemblages as indicators of Au enrichment in porphyry and epithermal deposits [54]. Although $\mathrm{Pb}$-bearing minerals (e.g., clausthalite, possible pasavaite) occur in samples containing precious metals, galena is relatively widespread in the ore and particularly at the periphery [46], suggesting $\mathrm{Pb}$ may not act as a definitive indicator for precious metals.

A challenge for precious metal beneficiation at Assarel is the very small size of the grains containing precious metals (sometimes, less than $1 \mu \mathrm{m}$ ) that likely poses difficulties for their liberation with economic efficiency. Therefore, from an ore dressing perspective, it is significant that Au is distributed in roughly equal proportions between $\mathrm{Cu}$-sulfides, pyrite, and groundmass quartz/silicates. In contrast, silver as the native metal and as sulfide was found only in quartz and in the rock groundmass, while Ag-selenide was identified in chalcopyrite and Ag-tellurides shared between pyrite and chalcopyrite. The palladium minerals were found only in pyrite grains. Considering these settings, part of the precious metal budget at Assarel may be recoverable during $\mathrm{Cu}$ extraction, while the remaining fraction would need additional, specific procedures to be efficiently extracted.

New drill core scanning technology (GeoCore X10; Figure 1) being developed within the X-MINE project [14] aims to complement and, if warranted, replace traditional methods of drill core assessment such as graphical logging and split-core geochemical assays. The method produces a digital archive of the scanned core using non-destructive means (XCT-XRF) from which 3D textural, structural, mineralogical, density, and geochemical data can be extracted in relatively short timeframes [15]. Such datasets provide a basis for further investigations including 3D deposit and/or resource modelling and better ore characterization for brown field exploration and geometallurgy $[16,17,45]$. Current factors that limit the applicability of this technology for precious metal quantification at Assarel are the spatial resolution of the tomographic images (ca. $200 \mu \mathrm{m}$ in standard mode, $100 \mu \mathrm{m}$ in high res, and $26 \mu \mathrm{m}$ reachable with a novel camera developed within X-Mine), which makes minute $(<10 \mu \mathrm{m})$ $\mathrm{Au}$, and PGE grains difficult to resolve. Although 68 of the naturally occurring chemical elements are analysed with each scan, the $\mathrm{Au}$ and PGE contents of the copper ore at Assarel is commonly less than 1 ppm [51] (Figure 3), which is lower than the current lower detection limit of the scanning instrument. Thus, the measurement of trace Au and PGE concentrations in drill core "digital assay intervals" is currently not possible, although the ability to scan for these is under development. However, composite average abundances for other elements relevant to porphyry $\mathrm{Cu}$ mineralization (e.g., $\mathrm{Cu}, \mathrm{S}, \mathrm{Mo}, \mathrm{Zn}, \mathrm{K}$, $\mathrm{Ba}, \mathrm{Sr}, \mathrm{Rb}$ ) over scan intervals wider than $7 \mathrm{~mm}$ are presently available.

Despite these analytical challenges, the potential for the rapid identification of key mineral assemblages, alteration zones or geochemical anomalies that control precious metal mineralization is currently feasible. For example, down-hole digital mapping of precious metal-bearing chalcopyrite and pyrite grains belonging to the main $\mathrm{CPH}$ assemblage and hosted in meso- to macroscopic veins could be used as a proxy for the 3D distribution of precious metal mineralization. Critically, however, this type of indirect approach which utilizes a priori knowledge about the character and setting of precious metals in the Assarel porphyry $\mathrm{Cu}$ ore highlights the need for independent validation and calibration of 3D core scanning technology based on detailed ore petrographic studies.

\section{Conclusions}

New petrographic results for drill core samples from the Assarel copper deposit indicate the occurrence of $\mathrm{Au}-, \mathrm{Ag}-, \mathrm{Bi}-, \mathrm{Te}-$, and Se-bearing minerals as minute inclusions in pyrite and chalcopyrite from the chalcopyrite-pyrite-magnetite \pm bornite $(\mathrm{CPM})$ and chalcopyrite-pyrite-hematite $(\mathrm{CPH})$ ore assemblages. Precious metals and minerals also occur within the quartz-silicate groundmass of variably propylitic-, sericitic-, and silicic-altered volcanic and porphyritic host rocks. We also report for the first time at Assarel the occurrence of several rare $\mathrm{Au}_{-}, \mathrm{Ag}-, \mathrm{Bi}_{-}, \mathrm{Cd}_{-}, \mathrm{Pd}_{-}, \mathrm{Sb}_{-}$, and 
Sn-bearing minerals including nagyágite, acanthite, bismuthinite, greenokite, sorosite, native nickel, and merenskyite, highlighting the compositional diversity of the mineralizing hydrothermal system. Ore samples associated with intense propylitic alteration contain a mineral assemblage that likely represents the imprint of the main mineralization stage (pyrite-chalcopyrite) on an earlier formed magnetite-chalcopyrite \pm bornite assemblage.

The occurrence of Ag and PGE as tellurides and selenides in the CPM and CPH mineralization from rocks with propylitic and sericitic-chloritic alteration indicates precious metals were at least partly introduced to the system by Te- and Se-bearing fluids during the early stages of porphyry mineralization. As the hydrothermal system evolved, $\mathrm{Bi}$ - and $\mathrm{Bi}-\mathrm{Cu}$ sulfides and acanthite precipitated as part of a sulfide-rich QP assemblage associated with sericitic alteration, indicating changes in the physicochemical parameters within the depositional environment.

The presence of hematite replaced and overgrown by chalcopyrite in sericitic-chloritic altered ore samples provides further evidence for intermittent and possibly rapid fluctuations in the redox conditions during mineralization. From an exploration perspective, anomalous Te and Bi values may be useful as tracers for precious metals, as they are spatially associated with Au, Ag and PGE.

The refined mineralogical assessment of the Assarel $\mathrm{Cu}$-Au ore presented in this study provides a basis for ongoing investigations that incorporate novel drill core 3D XCT-XRF scanning to digitally model the distribution of vein-hosted and disseminated $\mathrm{Cu}-\mathrm{Au}$ mineralization. Although the minute size $(<\mathrm{ca} .10 \mu \mathrm{m})$ and setting (sulfide-hosted inclusions) of precious metal minerals at Assarel represents a challenge to this nascent technology in terms of their spatial and chemical quantification, the identification of specific generations of host pyrite and chalcopyrite with respect to scanned mineral assemblages, alteration zones, structures, density, and/or geochemical anomalies (e.g., Au) provides a basis for further precious metal assessment within this and other porphyry copper deposit.

Supplementary Materials: The following are available online at http://www.mdpi.com/2075-163X/10/11/946/s1, Table S1. Samples description.

Author Contributions: Conceptualization, M.-E.C., M.M., and E.P.L.; petrographic investigation, M.-E.C., M.M., D.I., V.M., and V.S.; SEM-EDS investigation, M.-E.C., G.C., and A.I.-P.; project administration, M.M., E.P.L., R.A., N.A., and K.H.; resources, D.I., V.S., and M.B.; data curation, M.-E.C., E.P.L., D.I., and V.S.; writing-original draft preparation, M.-E.C. and M.M.; writing-review and editing, E.P.L., N.A., M.B., G.C., V.M., K.H., and D.I. All authors have read and agreed to the published version of the manuscript.

Funding: This research was funded by the European Union's Horizon 2020 research and innovation program, grant number 730270 .

Acknowledgments: The authors thank Assarel-Medet JSC for the assistance during the field work and sample collection at the mine site.

Conflicts of Interest: The authors declare no conflict of interest. The funders had no role in the design of the study; in the collection, analyses, or interpretation of data; in the writing of the manuscript, or in the decision to publish the results.

\section{References}

1. Sinclair, W.D. Porphyry deposits. In Mineral Deposits of Canada: A Synthesis of Major Deposits—Types. District Metallogeny, the Evolution of Geological Provinces, and Exploration Methods; Goodfellow, W.D., Ed.; Geological Association of Canada, Mineral Deposits Division, Special Publication no. 5: St. John's, NL, Canada, 2007; pp. 223-243.

2. McFall, K.A.; Roberts, S.; Teagle, D.; Naden, J.; Lusty, P.; Boyce, A. The origin and distribution of critical metals (Pd, Pt, Te and Se) within the Skouries Cu-Au porphyry deposit, Greece. Appl. Earth Sci. 2016, 125, 100-101. [CrossRef]

3. Crespo, J.; Reich, M.; Barra, F.; Verdugo, J.J.; Martinez, C. Critical Metal Particles in Copper Sulfides from the Supergiant Río Blanco Porphyry Cu-Mo Deposit, Chile. Minerals 2018, 8, 519. [CrossRef]

4. Agorhom, E.A.; Skinner, W.; Zanin, M. Influence of gold mineralogy on its flotation recovery in a porphyry copper-gold ore. Chem. Eng. Sci. 2013, 99, 127-138. [CrossRef] 
5. Sadegh Safarzadeh, M.; Horton, M.; Van Rythoven, A.D. Review of Recovery of Platinum Group Metals from Copper Leach Residues and Other Resources. Miner. Process. Extr. Metall. Rev. 2018, 39, 1-17. [CrossRef]

6. Zachariáš, J.; Pertold, Z.; Pudilová, M.; Zák, K.; Pertoldová, J.; Stein, H.; Markey, R. Geology and genesis of Variscan porphyry-style gold mineralization, Petráčkova hora deposit, Bohemian Massif, Czech Republic. Miner. Depos. 2001, 36, 517-541. [CrossRef]

7. Economou-Eliopoulos, M.; Eliopoulos, D.G. Mineralogical and geochemical characteristics of the Skouries porphyry-Cu-Au-Pd-Pt deposit (Greece): Evidence for the precious metal. In Mineral Deposit Research: Meeting the Global Challenge; Springer: Berlin/Heidelberg, Germany, 2005. [CrossRef]

8. Gray, C.A.; Rythoven, A.D. A Comparative Study of Porphyry-Type Copper Deposit Mineralogies by Portable X-ray Fluorescence and Optical Petrography. Minerals 2020, 10, 431. [CrossRef]

9. Lypaczewski, P.; Rivard, B.; Lesage, G.; Byrne, K.; D’Angelo, M.; Lee, R.G. Characterization of Mineralogy in the Highland Valley Porphyry $\mathrm{Cu}$ District Using Hyperspectral Imaging, and Potential Applications. Minerals 2020, 10, 473. [CrossRef]

10. Kauppinen, T.; Khajehzadeh, N.; Haavisto, O. Laser-induced fluorescence images and Raman spectroscopy studies on rapid scanning of rock drillcore samples. Int. J. Miner. Process. 2014, 132, 26-33. [CrossRef]

11. Haavisto, O.; Kauppinen, T.; Häkkänen, H. Laser-Induced Breakdown Spectroscopy for Rapid Elemental Analysis of Drillcore. IFAC Proc. Vol. 2013, 46, 87-91. [CrossRef]

12. Wells, M.A.; Ramanaidou, E.R. Raman Spectroscopic Core Scanning for Iron Ore and BIF Characterization. In Proceedings of the 11th International Congress for Applied Mineralogy (ICAM); Dong, F., Ed.; Springer: Berlin/Heidelberg, Germany, 2015; pp. 387-396. [CrossRef]

13. Kyle, J.R.; Mote, A.S.; Ketcham, R.A. High resolution X-ray computed tomography studies of Grasberg porphyry Cu-Au ores, Papua, Indonesia. Miner. Depos. 2008, 43, 519-532. [CrossRef]

14. Munteanu, M.; Sädbom, S.; Paaso, J.; Bergqvist, M.; Arvanitidis, N.; Arvidsson, R.; Kolacz, J.; Bakalis, E.; Ivanov, D.; Grammi, K.; et al. X-MINE project (H2020): Testing the capabilities of X-ray techniques in drill core scanning and ore sorting. In Proceedings of the EGU General Assembly Conference Abstracts, Online, 4-8 May 2020. [CrossRef]

15. Bergqvist, M.; Landström, E.; Hansson, A.; Luth, S. Access to geological structures, density, minerals and textures through novel combination of 3D tomography, XRF and sample weight. ASEG Ext. Abstr. 2019, 2019. [CrossRef]

16. Sahlström, F.; Jonsson, E.; Högdahl, K.; Ghaderidosst, J.; Luth, S.; Lynch, E.; Landström, E.; Sädbom, S. Textural evolution of the Lovisa $\mathrm{Zn}-\mathrm{Pb}-(\mathrm{Ag})$ deposit, Bergslagen, Sweden: Insights from microscopy and 3D X-ray tomography. In Proceedings of the 15th Biennial SGA Biennial Meeting, Glasgow, UK, $27-30$ August 2019; Volume 1, pp. 443-446.

17. Luth, S.; Sahlström, F.; Jansson, N.; Jönberger, J.; Sädbom, S.; Landström, E.; Bergqvist, M.; Arvanitidis, N.; Arvidsson, R. Building 3D geomodels using XRF-XCT-generated drillcore data: The Lovisa-Håkansboda base metal-and Stråssa-Blanka iron deposits in Bergslagen, Sweden. In Proceedings of the 15th Biennial SGA Meeting, Glasgow, UK, 27-30 August 2019; Volume 3, pp. 1282-1285.

18. Högdahl, K.; Johnsson, E.; Roško, S.; Wlodek, A.; Zack, T.; Landström, E.; Lynch, E.P.; Sahlström, F.; Tsitsanis, P.; Bacalis, V. Ore mineralogy, trace element distribution and 3D X-ray tomography of the polymetallic sulphide deposits at Mavres Petres and Piavitsa, Greece. In Proceedings of the 15th Biennial SGA Meeting, Glasgow, UK, 27-30 August 2019; Volume 1, pp. 279-282.

19. Andersson, J.; Warlo, M.; Bauer, T.E.; Bergqvist, M.; Hansson, A. Structural controls on sulphide (re)-distribution in Kiruna. In Proceedings of the 15th Biennial SGA Meeting, Glasgow, UK, 27-30 August 2019; Volume 1, pp. 115-118.

20. Delgado Yáñez, D. Geochemical and Mineralogical Comparison of XRT-XRF Scanning Technology Versus Traditional Analysis of Drill Core from the Assarel Porphyry Copper-Gold Deposit (Panagyurishte District, Bulgaria). Master's Thesis, Uppsala University, Uppsala, Sweden, 2020; p. 133.

21. Berza, T.; Constantinescu, E.; Vlad, S.N. Upper Cretaceous magmatic series and associated mineralisation in the Carpatho-Balkan orogeny. Resour. Geol. 1998, 48, 291-306. [CrossRef]

22. Ciobanu, C.L.; Cook, N.J.; Stein, H. Regional setting and geochronology of the Late Cretaceous Banatitic Magmatic and Metallogenic Belt. Miner. Depos. 2002, 37, 541-567. [CrossRef]

23. Tarkian, M.; Hunken, U.; Tokmakchieva, M.; Bogdanov, K. Precious-metal distribution and fluid-inclusion petrography of the Elatsite porphyry copper deposit, Bulgaria. Miner. Depos. 2003, 38, 261-281. [CrossRef] 
24. Handler, R.; Neubauer, F.; Velichkova, S.H. 40Ar/39Ar age constraints on the timing of magmatism and post-magmatic cooling in the Panagyurishte region, Bulgaria. Bull. Suisse Mineral. Petrogr. 2004, 84, 119-132.

25. Von Cotta, B. Erzlagerstätten im Banat und in Serbien; W. Braumüller: Vienna, Austria, 1864; p. 108.

26. Kamenov, K.B.; Yanev, Y.; Nedialkov, R.; Moritz, R.; Peytcheva, I.; von Quadt, A.; Stoykov, S.; Zartova, A. Petrology of Upper Cretaceous island-arc ore-magmatic centers from Central Srednogorie, Bulgaria: Magma evolution and paths. Geochem. Mineral. Petrol. 2007, 45, 39-77.

27. Popov, P.; Strashimirov, S.; Popov, K.; Petrunov, R.; Kanazirski, M.; Tzonev, D. Main features in geology and metallogeny of the Panagyurishte ore region. An. Univ. Min. Geol. 2003, 46, 119-125.

28. Popov, P.; Strashimirov, S.; Popov, K.; Kanazirski, M.; Bogdanov, K.; Radichev, R.; Stoykov, S. Geology and Metallogeny of the Panagyurishte ore Region; St. Ivan Rilski University of Mining and Geology: Sofia, Bulgaria, 2012; pp. 191-228.

29. Zimmerman, A.; Stein, H.J.; Hannah, J.L.; Koželj, D.; Bogdanov, K.; Berza, T. Tectonic configuration of the Apuseni-Banat-Timok-Srednogorie belt, Balkans-South Carpathians, constrained by high precision Re-Os molybdenite ages. Miner. Depos. 2008, 43, 1-21. [CrossRef]

30. Strashimirov, S.; Bogdanov, K.; Popov, K.; Kehayov, R. Porphyry system of the Panagyurishte ore region. In Cretaceous Porphyry-Epithermal Systems of the Srednogorie Zone, Bulgaria; Society of Economic Geologists Guidebook Series; Bogdanov, K., Strashimirov, S., Eds.; Society of Economic Geologists: Sofia, Bulgaria, 2003; Volume 36, pp. 47-78.

31. Chambefort, I.; Moritz, R. Late Cretaceous structural control and Alpine overprint of the high-sulfidation $\mathrm{Cu}$-Au epithermal Chelopech deposit, Srednogorie Belt, Bulgaria. Miner. Depos. 2006, 41, 259-280. [CrossRef]

32. Boccaletti, M.; Manetti, P.; Peccerillo, A. The Balkanids as an instance of back-arc thrust belt: Possible relation with the Hellenids. Geol. Soc. Am. Bull. 1974, 85, 1077-1084. [CrossRef]

33. Drew, L.J. A tectonic model for the spatial occurrence of porphyry copper and polymetallic vein deposits-Applications to Central Europe. In U.S. Geological Survey Scientific Investigations Report 2005-5272; U.S. Geological Survey: Reston, VA, USA, 2006; p. 36. Available online: https://pubs.usgs.gov/sir/2005/5272/ index.html (accessed on 9 September 2020).

34. Gallhofer, D.; von Quadt, A.; Peytcheva, I.; Schmid, S.M.; Heinrich, C.A. Tectonic, magmatic, and metallogenic evolution of the Late Cretaceous arc in the Carpathian-Balkan orogen. Tectonics 2015, 34, 1813-1836. [CrossRef]

35. Chambefort, I.; Moritz, R.; von Quadt, A. Petrology, geochemistry and U-Pb geochronology of magmatic rocks from the high-sulfidation epithermal Au-Cu Chelopech deposit, Srednogorie zone, Bulgaria. Miner. Depos. 2007, 42, 665-690. [CrossRef]

36. Dabovski, C.; Harkovska, A.; Kamenov, B.; Mavrudchiev, B.; Stanisheva-Vassileva, G.; Yanev, Y. A geodynamic model of the Alpine magmatism in Bulgaria. Geol. Balc. 1991, 21, 3-15.

37. Strashimirov, S.; Petrunov, R.; Kanazirski, M. Porphyry-copper mineralisation in the central Srednogorie zone, Bulgaria. Miner. Depos. 2002, 37, 587-598. [CrossRef]

38. Zartova, A.; Nedialkov, R.; Moritz, R. Petrology of magmatism of the Assarel copper porphyry deposit. In Proceedings of the Annual Conference Geology 2004, Sofia, Bulgaria, 16-17 December 2004; pp. 113-115.

39. Popov, P.; Popov, K. General geologic and metallogenic features of the Panagyurishte ore region. In Geodynamic and Ore Deposits Evolution of the Alpine-Balkan-Carpathian-Dinaride Province. Guide to Excursions $A$ and $C$. ABCD-GEODE Workshop. Borovets, Bulgaria, Guide to Excursions; Strashimirov, S., Popov, P., Eds.; Publishing house "St. Ivan Rilski", University of Mining and Geology "St. Ivan Rilski": Sofia, Bulgaria, 2000; pp. 1-7.

40. Kouzmanov, K.; Moritz, R.; von Quadt, A.; Chiaradia, M.; Peytcheva, I.; Fontignie, D.; Ramboz, C.; Bogdanov, K. Late Cretaceous porphyry $\mathrm{Cu}$ and epithermal $\mathrm{Cu}-\mathrm{Au}$ association in the Southern Panagyurishte District, Bulgaria: The paired Vlaykov Vruh and Elshitsa deposits. Miner. Depos. 2009, 44, 611-646. [CrossRef]

41. von Quadt, A.; Moritz, R.; Peytcheva, I.; Heinrich, C. Geochronology and geodynamics of Late Cretaceous magmatism and $\mathrm{Cu}$-Au mineralisation in the Panagyurishte region of the Apuseni-Banat-Timok-Srednogorie belt, Bulgaria. Ore Geol. Rev. 2005, 27, 95-127. [CrossRef]

42. Peytcheva, I.; von Quadt, A.; Heinrich, C.A.; Nedialkov, R.; Neubeaur, F.; Moritz, R. Medet and Assarel Cu-porphyry deposits in Central Srednogorie, SE Europe: Were they a common magmatic and hydrothermal system? In Proceedings of the 9th Biennial SGA Meeting, Dublin, Ireland, 20-23 August 2007; pp. 881-884.

43. Bogdanov, B.D. Porphyry-copper deposits of Bulgaria. Int. Geol. Rev. 1983, 25, 178-188. [CrossRef] 
44. Popov, P.; Petrunov, R.; Kohachev, V.; Stashimirov, S.; Kanazirski, M. Elatsite-Chelopech ore field. In Geodynamic and Ore Deposits Evolution of the Alpine-Balkan-Carpathian-Dinaride Province. Guide to Excursions A and C. ABCD-GEODE Workshop. Borovets, Bulgaria, Guide to Excursions; Strashimirov, S., Popov, P., Eds.; Publishing house "St. Ivan Rilski", University of Mining and Geology "St. Ivan Rilski": Sofia, Bulgaria, 2000; pp. 8-18.

45. Popov, P.; Strashimirov, S.; Kanazirski, M. Assarel-Medet ore field. In Geodinynamic and Ore Deposits Evolution of the Alpine-Balkan-Carpathian-Dinaride Province. Guide to Excursions A and C. ABCD-GEODE Workshop. Borovets, Bulgaria, Guide to Excursions; Strashimirov, S., Popov, P., Eds.; Publishing house "St. Ivan Rilski", University of Mining and Geology “St. Ivan Rilski”: Sofia, Bulgaria, 2000; pp. 19-25.

46. Popov, K. 3D modelling of the geochemical associations in the Assarel porphyry copper deposit (Bulgaria). Comptes Rendus l'Acad. Bulg. Sci. 2016, 69, 1175-1182.

47. Tsonev, D.; Popov, K.; Kanazirski, M. Krasen-Petelovo ore field. In Geodinynamic and Ore Deposits Evolution of the Alpine-Balkan-Carpathian-Dinaride Province. Guide to Excursions A and C. ABCD-GEODE Workshop. Borovets, Bulgaria, Guide to Excursions; Strashimirov, S., Popov, P., Eds.; Publishing house "St. Ivan Rilski", University of Mining and Geology "St. Ivan Rilski": Sofia, Bulgaria, 2000; pp. 26-31.

48. Tsonev, D.; Popov, K.; Kanazirski, M.; Stashimirov, S. Radka ore field. In Geodynamics and Ore Deposits Evolution of the Alpine-Balkan-Carpathian-Dinaride Province. Guide to Excursions A and C. ABCD-GEODE Workshop. Borovets, Bulgaria, Guide to Excursions; Strashimirov, S., Popov, P., Eds.; Publishing house “St. Ivan Rilski”, University of Mining and Geology “St. Ivan Rilski”: Sofia, Bulgaria, 2000; pp. 32-39.

49. Bogdanov, K.; Ciobanu, C.L.; Cook, N.J. Porphyry-epithermal Bi-Te-Se assemblages as a guide for gold ore enrichment. In Au-Ag-Telluride Deposits of the Golden Quadritrilateral, Apuseni Mt., Romania; Intern. Field Workshop of IGCP Project 486: Alba Iulia, Romania, 2004; pp. 211-214.

50. Nedialkov, R.; Zartova, A.; Moritz, R.; Bussey, F.; von Quadt, A.; Peytcheva, I.; Fontignie, D. Magmatic petrology and exsolution of ore bearing fluid in the magmatic center Assarel, Central Srednogorie, Bulgaria. In Proceedings of the XVIII Congress CBGA, Belgrade, Serbia, 3-6 September 2006; pp. 411-414.

51. Hikov, A. Geochemistry of hydrothermally altered rocks from the Assarel porphyry copper deposit, Central Srednogorie. Geol. Balc. 2013, 42, 3-28.

52. Sillitoe, R.H. The Carpathian-Balkan Porphyry Copper Belt-A Cordilleran Perspective. In European Copper Deposits, Proceedings of International Symposium, Bor, Yugoslavia, 18-22 September 1979; Jankovic, S., Sillitoe, R.H., Eds.; Department of Economic Geology, Faculty of Mining and Geology, Belgrade University: Belgrade, Serbia, 1980; pp. 26-34.

53. Tarkian, M.; Stribrny, B. Platinum-group elements in porphyry copper deposits: A reconnaissance study. Miner. Petrol. 1999, 65, 161-183. [CrossRef]

54. Nedialkov, R.; Zartova, A.; Moritz, R. Magmatic rocks and evolution of the Late Cretaceous magmatism in the region of the Asarel porphyry copper deposit, Central Srednogorie, Bulgaria. Rev. Bulg. Geol. Soc. 2007, $68,57-76$.

55. Iliev, K.; Katckov, N. Geological Map of Bulgaria-Panagyurishte; 1: 100 000-Scale; Bulgarian Committee on Geology, Enterprise for Geophysical Studies and Geological Mapping: Sofia, Bulgaria, 1990.

56. Gifkins, C.; Herrmann, W.; Large, R. Altered Volcanic Rocks. A Guide to Description and Interpretation; Centre for Ore Deposit Research, University of Tasmania: Tasmania, Australia, 2005; p. 275.

57. Thompson, A.J.B.; Thompson, J.F.H. Atlas of Alteration. A Field and Petrographic Guide to Hydrothermal Alteration Minerals; Geological Association of Canada, Mineral Deposits Division: St. John's NL, Canada, 1996; p. 119.

58. Singer, D.A.; Berger, V.I.; Moring, B.C. Porphyry Copper Deposits of the World: Database and Grade and Tonnage Models, 2008; Open-File Report 2008-1155; United States Geological Survey: Reston, VA, USA, 2008; p. 45. Available online: https://pubs.usgs.gov/of/2008/1155/ (accessed on 9 September 2020).

59. Seedorf, E.; Dilles, J.H.; Proffett, J.M., Jr.; Einaudi, M.T.; Zurcher, L.; Stavast, W.J.A.; Johnson, D.A.; Barton, M.D. Porphyry deposits: Characteristics and origin of hypogene features. In Economic Geology 100th Anniversary Volume; Hedenquist, J.W., Thompson, J.F.H., Goldfarb, R.J., Richards, J.P., Eds.; Society of Economic Geologists, INC.: Littleton, CO, USA, 2005; pp. 251-298. Available online: https://pubs.usgs.gov/of/2008/1155/ (accessed on 9 September 2020).

60. Zhao, J.; Brugger, J.; Chen, G.; Ngothai, Y.; Pring, A. Experimental study of the formation of chalcopyrite and bornite via the sulfidation of hematite: Mineral replacements with a large volume increase. Am. Miner. 2014, 99, 343-354. [CrossRef] 
61. Keith, M.; Smith, D.J.; Jenkin, G.R.T.; Holwell, D.A.; Dye, M.D. A review of Te and Se systematics in hydrothermal pyrite from precious metal deposits: Insights into ore-forming processes. Ore Geol. Rev. 2018, 96, 269-282. [CrossRef]

62. Communication from the Commission to the European Parliament, the Council, the European Economic and Social Committee and the Committee of the Regions. Critical Raw Materials Resilience: Charting a Path towards Greater Security and Sustainability; European Commission: Brussels, Belgium, 2020; COM (2020), 474 Final; Available online: https://eur-lex.europa.eu/legal-content/EN/TXT/HTML/?uri=CELEX: 52020DC0474\&from $=$ EN (accessed on 9 September 2020).

63. Cook, N.J.; Ciobanu, C.L.; Spry, P.G.; Voudouris, P. and the participants of IGCP-486. Understanding gold-(silver)-telluride-(selenide) mineral deposits. Episodes 2009, 32, 249-263. [CrossRef]

Publisher's Note: MDPI stays neutral with regard to jurisdictional claims in published maps and institutional affiliations.

(C) 2020 by the authors. Licensee MDPI, Basel, Switzerland. This article is an open access article distributed under the terms and conditions of the Creative Commons Attribution (CC BY) license (http://creativecommons.org/licenses/by/4.0/). 